\title{
A LONG, STRANGE TRIPS: THE PHARMACEUTICAL INDUSTRY DRIVE TO HARMONIZE GLOBAL INTELLECTUAL PROPERTY RULES, AND THE REMAINING WTO LEGAL ALTERNATIVES AVAILABLE TO THIRD WORLD COUNTRIES
}

\author{
ROBERT WEISSMAN*
}

\section{INTRODUCTION}

One of the great ironies of the recent drive to global free trade - evidenced most notably in the negotiation and implementation of the North American Free Trade Agreement ("NAFTA") 1 and the Uruguay Round of the General Agreement on Tariffs and Trade ("GATT") - is the inclusion of intellectual property on the free trade bandwagon. By definition, protecting intellectual property is about restricting trade in certain goods. And the pharmaceutical industry in the United States, the beneficiary of massive subsidies and border protection against unwanted import competition, has played a critical role in placing intellectual property protection on the free trade agenda.

Yet, ironic or not, intellectual property protection has become a central part of the free trade agenda, as well as the major global trade agreements. This Article considers how this state of affairs

Editor, Multinational Monitor and Director of Essential Information's International Projects (Washington, D.C.). J.D. 1995, Harvard Law School. Special thanks to Eben Moglen, as well as to Gregory T. Parks and the University of Pennsylvania Journal of International Economic Law editing team.

1 See North American Free Trade Agreement, Dec. 17, 1992, Can.-Mex.U.S., 32 I.L.M. 289 (1993), 32 I.L.M. 605 (1993), reprinted in THE NAFTA (U.S. Gov't Printing Office ed., 1993); see also North American Free Trade Agreement Implementation Act, Pub. L. No. 103-182, 107 Stat. 2057 (1993) (implementing necessary changes in U.S. law to comply with NAFTA and reprinting the agreement).

2 See Final Act Embodying the Results of the Uruguay Round of Multilateral Trade Negotiations, Apr. 15, 1994, LEGAL INSTRUMENTS RESULTS OF THE URUGUAY ROUND vol. 1 (1994), 33 I.L.M. 1125 (1994) [hereinafter Final Act]. 
came about, and what it means for the Third World. Its crucial concern is the range of pharmaceutical patent policy options that remain open to Third World nations in the wake of the successful conclusion of the Uruguay Round and the ensuing establishment of the World Trade Organization ("WTO").

Section 2 provides some background on the range of possible patent regimes. The goal of this section is to emphasize that there is more than a single approach to patent policy. There are viable alternatives to U.S.-style laws that current strict protectors of patents have historically used.

Section 3 recounts the U.S. pharmaceutical industry's political offensive over the last fifteen years designed to force all nations to adopt restrictive patent laws on the model of the United States. Restrictive in this context means that they grant more rather than less control to the patent holder. Restrictive patent rules are therefore the sort preferred by pharmaceutical patent holders. This section is itself divided into two parts. The first part describes the maneuverings and power plays the pharmaceutical industry has used with tremendous success to advance its global interests. The second part focuses on the way the debate over global patent policy has been framed - the language, metaphors and, imagery characterizing the debate and how they have shaped conceptions about property, particularly conceptions of moral right. This part further shows how the pharmaceutical industry is attempting - on the political level, and in the way it frames its arguments - to suppress alternatives to its preferred intellectual property regime. By elucidating this effort, this part attempts to reinforce the very point the industry is trying to obscure: that there are alternatives.

Section 4 undertakes a close analysis of the GATT Trade Related Aspects of Intellectual Property Agreement ("TRIPS" or "the Agreement"), the basic thrust of which is to require all signatory nations to adopt U.S.-style patent laws. This part argues that despite its highly restrictive appearance, the Agreement in fact leaves a number of options open to Third World signatory nations. Under the Agreement, these countries must provide

${ }^{3}$ See Agreement on Trade-Related Aspects of Intellectual Property Rights [hereinafter TRIPS Agreement], Apr. 15, 1994, Marakesh Agreement Establishing the World Trade Organization, Annex 1C, art. 66, para. 1, LEGAL INSTRUMENTS - RESULTS OF THE URUGUAY ROUND vol. 31; 33 I.L.M. 81 (1994). 
some patent protection, but it can differ in significant ways from the protections of U.S. law.

Section 5 considers the costs and benefits of various patent policy alternatives. It focuses especially on compulsory licensing schemes. The concluding part of this Article outlines a patent policy approach for Third World nations that conforms to the TRIPS Agreement and would better serve their national interests than strict U.S.-style laws.

\section{PATENT POLICY OPTIONS}

\subsection{Patent Policy Rationale}

The logic underlying the creation of patents ${ }^{4}$ is familiar: while society wants knowledge in the public domain, inventors need protection for their innovations in order to maintain an incentive for creative inquiry. ${ }^{5}$ The inventor could provide herself some protection by withholding information regarding the specifics of her invention. However, this would keep the information out of the public domain. The attraction of the patent, in addition to certain enforcement and administrability benefits, is that the inventor immediately places her newly-created knowledge in the public domain. In exchange, she receives exclusive rights to use the patented knowledge for a limited period of time. ${ }^{6}$

Justified even on its own terms, the patent is not an unmitigated good. Rather, it represents a compromise between competing interests. ${ }^{7}$ While the patent represents a positive good to the extent that it provides desirable protection to inventors, it represents a compromise from the perspective of public use. ${ }^{8}$ It

4 In the United States, for example, patents are awarded for new, useful, and nonobvious products or processes, or new, useful and nonobvious improvements to existing products or processes. See 35 U.S.C. $\$ \$ 101,103$ (a) (1994).

5 See Gary Myers, The Restatement's Rejection of the Misappropriation Tort: A Victory for the Public Domain, 47 S.C. L. REV. 673, 685 (1996) (proclaiming the virtues of a system "which can provide protections sufficient to offer suitable incentives to create, while also limiting those rights in a manner that will permit broad access to information").

${ }^{6}$ For example, in the United States, that period of time is 20 years. See 35 U.S.C. $\$ 154(\mathrm{a})(2)(1994)$.

7 See Wendy J. Gordon, Comment, Assertive Modesty: An Economics of Intangibles, 94 COLUM. L. REV. 2579, 2593 n.8 (1994) (explaining the policy balance involved).

8 See id. 
does accomplish its stated goal of placing information regarding the newly invented item in the public domain, but it does so at the expense of conditioning the right to use this information commercially on securing a license from the patent holder. A license can usually only be acquired for a fee and, in the case of pharmaceuticals, is often not available for any feasible price.

\subsection{Specific Policy Options}

As applied to pharmaceuticals, or any product, there is a wide range of options in striking the balance between competing interests, some of which can be pursued in conjunction with others.

\subsubsection{U.S.-Style Patent Protections}

At one end of the spectrum is the strict U.S. patent regime. ${ }^{9}$ The U.S. system provides twenty years of patent protection for both processes and products. ${ }^{10}$ There are no compulsory terms for patent holders, who are free to license or not license their patent, to use it or let it lie dormant for its entire life. ${ }^{11}$

\subsubsection{No Patents}

At the other end of the spectrum is a no-patent regime. Until recently, Argentina and Brazil had no-patent systems for pharmaceuticals. ${ }^{12}$ Companies were free to copy and sell pharmaceuticals invented by other companies, even if patented in other countries, without penalty. ${ }^{13}$ Unlike $C D$ copying in China, which has been the object of so much recent attention and fury, ${ }^{14}$ pharmaceutical companies in Argentina and Brazil engaged in copying were not violating domestic law.

9 See 35 U.S.C. $\$ \$ 101-203$ (1994).

${ }^{10}$ See 35 U.S.C. $\$ 154(a)(2)(1994)$.

11 See 35 U.S.C. \$S 101-203 (1994).

12 See Bruce Rubenstein, Latin American Slow to Protect Patents Under Nafta, CORP. LEGAL TIMES, v. 6, No. 52, Mar. 1996, at 17 (discussing Brazil's reluctance to implement any patent scheme); Argentina: No Patents for Drugs Till 2005, MARKETLETTER, Nov. 7, 1994, at 11 (stating that even if Argentina's Congress passed the contemplated patent bill, pharmaceuticals would not enjoy patent protection until the year 2005).

${ }^{13}$ See Rubenstein, supra note 12, at 17.

14 See Paul Blustein, U.S. Warns China to Step Up Efforts Against 'Piracy', WASH. POST, Nov. 30, 1995, at B13. 


\subsubsection{Process Versus Product Patents}

One in-between position is to issue patents only on products and not on processes, or only on processes and not on products. ${ }^{15}$ Until recently, India's patent scheme was process-only for pharmaceuticals. ${ }^{16}$ A drug inventor could patent the process by which he produced a pharmaceutical, but not the drug itself. ${ }^{17}$ Another producer was free to synthesize the same drug if she was able to develop another industrial process to do so. ${ }^{18}$

\subsubsection{Different Length of Terms}

The period of patent protection can be shortened or lengthened. Although the United States long held its seventeen year period inviolate, ${ }^{19}$ there is no inherent reason why the protection could not be afforded for only ten years - or thirty years, for that matter.

\subsubsection{Compulsory Licensing}

In a compulsory licensing scheme, U.S.-style patents are granted, with one major caveat. During the patent's exclusive term, patent holders are required to grant non-exclusive licenses to competitors, or any entity that wants to use the patent, in exchange for a reasonable licensing fee. ${ }^{20}$ Until recently, Canada maintained a compulsory licensing system for pharmaceuticals. ${ }^{21}$

15 For a summary of the arguments respecting process patents, see generally Lara L. Douglass, Note, Medical Process Patents: Can We Live Without Them? Should We?, 3 J. INTELL. PROP. L. 161 (1995).

16 See Martin J. Adelman \& Sonia Baldia, Prospects and Limits of the Patent Provision in the TRIPS Agreement: The Case of India, 29 VAND. J. TRANSNAT'L L. 507, 520 (1996).

17 See Gerald J. Mossinghoff, Research-Based Pharmaceutical Companies: The Need for Improved Patent Protection Worldwide, 2 J.L. \& TECH. 307, 311 (1987). ${ }_{18}$ See id.

19 Although the United State first afforded patent protection in 1793, the term of patent protection was only 17 years until 1994. See Pub. L. No. 103465, $\$ 532(a)(1), 108$ Stat. 4809, 4984 (1994) (amending 35 U.S.C. \$ 154 (1988)).

${ }^{20}$ For examples and an overview of compulsory licensing systems throughout the world, see Gianna Julian-Arnold, International Compulsory Licensing: The Rationales and the Reality, 33 J.L. \& TECH. 349 (1993).

${ }^{21}$ See Janet Hamilton, What's Going on in Intellectual Property Law?, 84 AM. SOC'Y INT'L L. PROC. 256, 258 (1990). 


\subsubsection{Work-the-Patent Requirements}

These requirements have at least two variants. In one, a patent holder who does not "work the patent" - that is, bring it to the market, either as its own good or as a component in another good - within a certain time frame loses his patent rights. This policy addresses the concern that giant companies might file for and control huge numbers of patents, thereby locking up domains of knowledge, even though they do not put the patented knowledge to use. This purely anti-competitive activity undermines the public policy balancing embodied in the initial grant of a patent. This type of work-the-patent requirement probably has little applicability to the pharmaceutical industry. In contrast, the second work-the-patent variant applies directly to the drug industry. It requires a patent holder to literally "work the patent" in the country where it holds the patent. For example, if Uruguay had such a requirement, and Johnson \& Johnson took out a patent on a new drug, it could not meet this requirement merely by selling the new drug in Uruguay. It would have to produce the new drug in Uruguay or lose patent protection there.

\subsubsection{Tax Schemes}

Taxes can be levied on the sale of patented goods, with the proceeds allocated to purposes such as domestic research. This would allow a country to reap the benefits of economic advantage from the patents and re-invest those benefits in furthering scientific knowledge.

\subsubsection{Price Controls}

A nation can seek to limit drug prices by instituting a partial or across-the-board system of price controls on pharmaceuticals. Price controls on pharmaceuticals are common throughout the industrialized world. ${ }^{22}$

\subsection{Modern Patent Policies}

Most industrialized countries now maintain strict patent

22 See, e.g., H.R. 3600, 103d Cong., 2d Sess., tit I(f), $\ 1572$ (1994) (containing President Clinton's recent proposal for drug price controls). 
regimes, but many of those nations only adopted strict patent laws in recent years. ${ }^{23}$

After World War II, many Third World nations began experimenting with the range of patent policy variations. ${ }^{24}$ This experimentation became more purposeful in the 1960 s and early 1970 s, when a call for a new international economic order arose from the Third World. ${ }^{25}$ Third World policy makers focused attention on the issue of technology transfer. ${ }^{26}$ No-patent regimes, compulsory programs, and process patent systems all attracted the attention of Third World governments and were used increasingly by these countries. ${ }^{27}$

\section{The Pharmaceutical Industry OfFENSIVE}

\subsection{Political Maneuvering}

By the late 1970 s, the momentum underlying the call for a new international economic order had slowed significantly. With the election of Ronald Reagan in 1980, the momentum shifted direction. By 1985, the pharmaceutical industry was on the offensive, in an effort to force Third World countries to adopt U.S.-style patent laws. ${ }^{28}$ While the industry attempted to directly persuade Third World policy makers of the merits of guaranteeing strict patent protection, its main strategy was to persuade U.S. policy makers to coerce Third World countries to adopt restrictive patent rules. ${ }^{29}$

The U.S. pharmaceutical industry trade association - until recently known as the Pharmaceutical Manufacturers Association ("PMA") and now called the Pharmaceutical Research and

23 See infra note 113 and accompanying text.

24 See GARY GEREFFI, THE PHARMACEUTICAI INDUSTRY AND DEPENDENCY IN THE THIRD WORLD 3 (1983) [hereinafter GEREFFI, PHARMACEUTICAL INDUSTRY] (stating that "modernization theory arose after World War II").

${ }^{25}$ See id. at 128-35 (ciring the example of Mexico's "new major policy initiatives" in this time period).

${ }^{26}$ See id. at 202-03 (citing India's attempts to transfer technology from transnational corporations to domestic industries through the use of various altered policies).

27 See id.

28 See Julie Kosterlitz, Rx: Higher Prices, NAT'L J., Feb. 13, 1993, at 76.

29 See id. 
Manufacturers Association ("PhRMA") 30 - became one of the most aggressive and high profile trade groups in Washington. ${ }^{31}$ The PMA hired Gerald Mossinghoff, Assistant Commerce Secretary and Commissioner of Patents and Trademarks in the Reagan administration from 1981 to 1985 , as its president. ${ }^{32}$ Other prominent government officials also spun through the revolving door between government and the pharmaceutical industry. For example, PMA vice president Harvey E. Bale Jr. worked at the Office of the U.S. Trade Representative ("USTR") for twelve years, leaving in $1987 .{ }^{33}$ David Bier, vice president for government affairs at Genentech Inc., a San Francisco-based biotechnology company, formerly worked on trade and intellectual property matters for the House Judiciary Committee. ${ }^{34}$

Representatives of the PMA and individual pharmaceutical companies acquired seats on important advisory boards that shape government policy. Executives from Dow Chemical Co., Johnson $\&$ Johnson, Merck, and other pharmaceutical firms became part of a special presidential trade advisory group. ${ }^{35}$ Senior officials from the PMA, Pfizer, and Immunon Technologies ${ }^{36}$ joined a technical advisory committee to the USTR on intellectual property rights. ${ }^{37}$ Officials from DuPont, Monsanto and Procter \& Gamble, each of which has significant pharmaceutical interests, also served on the advisory committee. ${ }^{38}$ The industry also undertook aggressive high-profile lobbying campaigns, testifying frequently before Congressional committees about the need to secure greater patent protection abroad. One significant element of the industry's political campaign was the funding of academic

${ }^{30}$ See Victor Ostrowidski, A New Look at the PMA: Pharmaceutical Manufacturers Association Changes Name to Pharmaceutical Research and Manufacturers Association, AM. DRUGGIST, June 1, 1994, at 11.

31 See Kosterlitz, supra note 28, at 77.

32 See id.

33 See id. ("Bale concedes that his connections are a plus for PMA. 'I hope so,' he said. 'I don't hide it. In fact, I'm happy to help them out.'”).

${ }^{34}$ See id.

35 See id.

${ }^{36}$ Immunon Technologies is a Bedford Hills, New York, biotechnology firm. See id.

${ }^{37}$ See id.

${ }^{38}$ See id. 
studies proclaiming the merits of strict patent protections. ${ }^{39}$

Although the industry would come under attack domestically in the 1980 s and 1990s for maintaining inflated prices on domestic sales, the campaign for the U.S. government to adopt the industry's international goals as its own met with tremendous success. ${ }^{40}$ Framing other nations' intellectual property regimes as a U.S. trade issue, ${ }^{41}$ the pharmaceutical industry succeeded in making strict international protection of intellectual property a central goal of U.S. international economic policy.

The industry's success manifested itself in at least three ways. First, the Office of the USTR exerted extraordinary pressure on individual Third World countries to adopt U.S.-style patent laws. ${ }^{42}$ Second, intellectual property protection became a central component of NAFTA, and promises to be included in any additional regional free trade agreements involving the United States. ${ }^{43}$ Third, and most importantly, the United States insisted that intellectual property protection be included in the Uruguay Round GATT negotiations, which began in 1986 and finally concluded in 1994.4

39 See id.

40 U .S. Trade Representative Clayton K. Yeutter recalls that when he left government service at the end of the Ford administration, hardly anyone in Washington had ever heard of the notion of intellectual property. He returned to government two years ago to find it one of the hottest buzzwords in town. 'Intellectual property issues have become central to congressional debate on trade policy,' says Sen. Patrick Leahy (D-Vt.).

John Burgess, Fighting Trespassing on "Intellectual Property": U.S. Tries to Prevent Overseas Copying of Everything From Music to Microchips, WASH. POST, Dec. 6, 1987, at $\mathrm{H} 1$.

${ }^{41}$ The industry's success in framing its goal of securing strict patent protection in other countries was itself a victory. This is especially true in light of the disparity between the industry's objectives and the traditional domain of international trade policy - which was primarily focused on tariff and related matters. See Curtis Reitz, Enforcement of the General Agreement on Tariffs and Trade, 17 U. PA. J. INT'L ECON. L. 555, $559-79$ (1996) (discussing the history and legacy of the GATT system prior to the Uruguay Round).

42 See Burgess, supra note 40, at $\mathrm{H1}, \mathrm{H} 4$ (detailing the extensive pressure exerted by various U.S. government authorities, including the USTR).

${ }^{43}$ See International Agreements: Intellectual Property Enforcement to Play Major Role in NAFTA Talks, 8 Int'l Trade Rep. (BNA) No. 42, at 1553 (Oct. 23, 1991).

${ }_{44}$ See Burgess, supra note 40 , at $\mathrm{H} 4$. 


\subsubsection{Section 301}

Beginning in the mid-1980s, the Office of the USTR, acting on the authority conferred on it by Section 301 of the Trade Act of 1974 , undertook an annual rite of placing countries which did not provide adequate protection to U.S. intellectual property on "watch lists" and "priority watch lists." 45 Those countries placed on watch lists were notified that the United States would impose trade sanctions upon them (in the form of tariffs on their exports to the United States) if they did not reform their patent laws. ${ }^{46}$ The process was intensified after 1988, when Congress enacted "Special 301" of the 1988 Trade Act, a provision which required the USTR to impose sanctions on countries which did not revise their patent laws. ${ }^{47}$

Although the USTR placed several dozen countries on watch lists, the main targets of USTR sanction threats were large Third World countries that had begun to develop domestic industries to compete against U.S. pharmaceutical manufacturers in their domestic market: India, Argentina, Brazil, Taiwan, and Thailand. ${ }^{48}$ Some observers speculated that the USTR focused particularly on India and Brazil because of their leading role in advancing Third World demands in GATT negotiations. ${ }^{49}$

In October 1988, for the first time in the intellectual property arena, the United States acted on its trade sanction threats. ${ }^{50}$ Acting in response to a petition filed by the PMA, ${ }^{51}$ and following lengthy negotiations, the Reagan administration imposed $100 \%$ tariffs on thirty-nine million dollars worth of Brazilian imports. ${ }^{52}$

45 See Hills Removes Taiwan, Korea, Saudia Arabia from Priority List, Five Countries Remain, 6 Int'l Trade Rep. (BNA) No. 44, at 1436 (Nov. 8, 1989).

46 See id.

47 See Kantor Singles Out Brazil, India, Thailand for Special 301 Designation, 10 Int'l Trade Rep. (BNA) No. 18, at 726 (May 5, 1993).

48 See id.

49 See Reagan, Charging Patent Piracy, Imposes Sanctions on $\$ 39$ Million of Brazilian Goods, 5 Int'l Trade Rep. (BNA) No. 42, at 1415 (Oct. 26, 1988) (reporting on comments from foreign relations officials in Brazil).

50 See id.

51 In addition to requiring certain action by the USTR, Section 301 and Special 301 allow private parties to petition the Trade Representative to impose sanctions against a country for discriminating against U.S. products. See id.

52 See id. 
The government claimed that this amount was equivalent to the market loss to U.S. pharmaceutical makers arising from Brazil's relative lack of patent protections for pharmaceuticals. ${ }^{53}$ The Brazilian government and media reacted with outrage. Reflecting popular sentiment, Veja, a leading Brazilian weekly, headlined its story on the sanctions as "The Empire Strikes Back." ${ }^{54}$ The Brazilian government denounced the U.S. exercise in big power unilateralism as illegal under GATT, claiming that the thenexisting version of the trade agreement required member countries to arbitrate disputes through the GATT dispute settlement machinery. 55

The sanctions, and a change of government, succeeded in changing Brazil's patent laws - though still not to U.S. satisfaction. In 1990, when the neo-liberal government of new President Fernando Collor de Mello agreed to revise its patent law to provide for strong patent protections, the United States lifted the sanctions. ${ }^{56}$ The 1990 agreement ameliorated the tension in the United States-Brazil conflict, but it did not completely eliminate the friction. The USTR placed Brazil on its priority watch list in

${ }^{53}$ See id. The Office of the USTR stated:

'The President declared his intention to take this action on July 22, 1988 at the conclusion of an unfair trade investigation under section 301 of our trade laws, following over two years of unsatisfactory bilateral consultations,' [then-USTR] Clayton Yeutter said. 'Pharmaceutical and chemical companies have little motivation to invest in the research and development of products important to mankind unless they are assured that the right to market those products will be safeguarded by patent protection. Patent piracy simply cannot go unchallenged.'

Press Release From the Office of the United States Trade Representative on President Reagan's Decision to Impose Trade Sanctions Against Brazil, FEDERAI. NEws SERVICE, Oct. 20, 1988, available in LEXIS, News Library, Arcnws File.

54 See Julia Michaels, U.S. Sanctions Over Drug Patents Brings Sharp Words From Brazil, THE CHRISTIAN SCI. MONTOR, Oct. 25, 1988, at 1 (quoting the Veja article).

55 "Paulo Tarso Flecha de Lima, Brazilian foreign ministry's No. 2 official, told a news conference that the sanctions are 'illegal, truculent, unjustified and do not have the support of international law.'" William R. Long, Brazil Blasts U.S.-Imposed Trade Sanctions as "Illegal" and "Unjustified", L.A. TIMES, Oct. 22, 1988 , at 2.

${ }_{56}$ See Hills Lifts $\$ 40$ Million in Sanctions After Brazil Pledges to Enact Patent Law, 7 Int'l Trade Rep. (BNA) No. 27, at 996-97 (July 4, 1990). 
1991 and 1992, ${ }^{57}$ and named Brazil one of the worst offenders of intellectual property rights (a "priority foreign country") in 1993.58

With some variation, the USTR applied the same sort of persistent pressure to the other countries designated as primary infringers of U.S. companies' intellectual property. Thailand and Taiwan both agreed to substantial changes in their patent laws, largely because of U.S. pressure. ${ }^{59}$ India and Argentina essentially withstood the direct pressure from the USTR.

\subsubsection{NAFTA}

The inclusion of intellectual property protection in NAFTA required that both Mexico and Canada change their patent laws. These changes were resisted most strongly in Canada, which had long maintained a compulsory licensing scheme. ${ }^{60}$

In 1987, Canada revised its Patent Act to provide patent protection for seven to ten years before triggering its compulsory licensing requirements. ${ }^{61}$ Although welcomed by the Canadian and U.S. pharmaceutical companies at the time, those changes left Canadian law far short of U.S. standards. ${ }^{62}$ NAFTA provided an opportunity for the industry to address this shortfall. Indeed, on February 4, 1993, Canada enacted Bill C-91, replacing its compulsory system with a U.S.-style regime. ${ }^{63}$

But this change only came after a long and bitter fight. That fight was predictable, given the prevailing analysis that "[ $t]$ here's one point everyone agrees on: The federal government's new

57 See USTR Cites India, Tairean, Thailand as Worst Intellectual Property Offenders, 9 Int'l Trade Rep. (BNA) No. 19, at 784-85 (May 6, 1992).

58 See Kantor Singles Out Brazil, India, Thailand for Special 301 Designation, 10 Int'l Trade Rep. (BNA) No. 18, at 726 (May 5, 1993). The United States insisted that Brazil's patent protections were too short, and complained about working requirements and compulsory licensing provisions. See id.

59 See Peter Ungphakorn, Thais Pass Bill After American Patent Demands, FIN. TIMES, Feb. 28, 1992, at 3; Taizean Strengthens Patent Lawes to Help GATT Entry, Reuters, Dec. 25, 1992, available in LEXIS, News Library, Arcnws File.

${ }_{60}^{60}$ See Kosterlitz, supra note 28, at 76.

61 See Act of Nov. 19, 1987, ch. 41, 1987 S.C. 1171 (Can.).

${ }^{62}$ See id.

63 See Patent Act Amendments Receive Royal Assent, Canada NewsWire, Feb. 4, 1993, available in LEXIS, News Library, Arcnws File. 
patent plan will raise drug prices." ${ }^{\text {"64 }}$ Estimates of the cost to Canadian consumers of passage of C-91 ranged as high as seven billion Canadian dollars over a twenty-year period. ${ }^{65}$ In the face of these estimates of skyrocketing prices, the industry promised that, if the bill were passed, it would invest an additional $\$ 530.6$ million in research in Canada, raising its percentage of profits devoted to research from eight to ten. ${ }^{66}$

Opponents of the patent law reform included the thenopposition Liberal Party, the Canadian generic drug industry, consumer advocates, health activists, and all of the country's provincial governments. ${ }^{67}$ They harped on the expected cost of the change. ${ }^{68}$ Opponents also emphasized the consequences of Canada's previous stronger patent policy enacted in 1987: drug costs had risen; only approximately 400 of the 3,000 new research jobs promised by the industry had been created; little basic drug research took place in Canada; and Canada had gained little ability to manufacture the active ingredients of drugs. ${ }^{69}$ Opponents lobbied hard and undertook a substantial public education effort, but their efforts fell for naught. ${ }^{70}$ The Conservative Party then held an absolute majority in Parliament, rendering the result of the fight predetermined once the government committed itself to Bill C-91. ${ }^{71}$ The generic industry also unsuccessfully sought to prevent enactment of C-91 by legal action, claiming it violated the 1987 Patent Act's provision precluding further revisions to the

${ }^{64}$ Ian Austen, Side Effects Unknown: Estimates of Cost, Real Impact of New Law Vary Wildly, OTTAWA CITIZEN, Dec. 6, 1992, at A7.

${ }_{65}^{65}$ See id.

66 See Canadian C-91 Goes to the Senate, MARKETLETTER, Dec. 21, 1992, available in LEXIS, News Library, Arcnws File.

${ }^{67}$ See Shawn McCarthy, Provinces Try Last-Ditch Plea to Halt Drug Bill, TORONTO STAR, Nov. 18, 1992, at A10. In Canada's highly decentralized governing system, the provinces are largely responsible for running the health care system, and it is the provinces who will be forced, in significant part, to bear whatever increased costs attach to C-91. See id.

${ }^{68}$ See id.

69 See Ian Austen, Few Benefits from 1987 Drug-Patent Changes: Study; Despite Report, Ottawa Moves to Further Reduce Competition in Pharmaceutical Industry, GAZETTE (Montreal), Sept. 17, 1992, at E3.

70 See Canada's Bill C-91 Almost There, PHARMaceutical Bus. News, Dec. 18, 1992, available in LEXIS, News Library, Arcnws File.

71 See id. 
country's patent law for a ten-year period. ${ }^{72}$

All parties saw the passage of C-91 as a victory for the U.S. pharmaceutical industry, and one orchestrated by the industry as well. The Canadian industry is effectively a subset of the U.S. industry. The Pharmaceutical Manufacturers Association ("PMA") of Canada is a mere fief of the U.S. PMA. Among the "Canadian" companies pledging to increase their Canadian research if C-91 passed were: Marion Merrell Dow, Merck Frosst Canada, BristolMyers Squibb, Pfizer Canada, Eli Lilly Canada, and Upjohn. ${ }^{73}$ It seemed clear that the U.S. companies were able to advance their interests through their branch operations and subsidiaries in Canada. These companies also lobbied from the U.S. side of the border. One manifestation of the U.S. industry's influence appeared in a letter to then-USTR Carla Hills from the Intellectual Property Committee, a coalition of thirteen major U.S. companies including DuPont, Merck, Pfizer, IBM, General Electric, and General Motors. ${ }^{74}$ The letter included negotiating instructions and specific demands for inclusions in NAFTA to satisfy industry. ${ }^{75}$ The letter was leaked in Canada, sparking outrage ${ }^{76}$ The success of the U.S. industry in securing patent provisions in NAFTA was perhaps best summarized by Edgar G. Davis, former vice president of Eli Lilly and now professor at Harvard University's Kennedy School of Government." Davis boasts that putting the patent provisions in NAFTA was "a master stroke, [demonstrating] what an industry that has its act together can accomplish."'78

\subsubsection{The GATT Attack}

The industry's success through 301 actions and NAFTA were critically important. It was able to set an example by targeting the most prominent opponents of alternative pharmaceutical

72 See id.

73 See id.

74 See Linda Diebel, How U.S. Drug Lobby Put New Patent Law Atop Canada's Agenda, TORONTO STAR, Dec. 6, 1992, at A1.

75 See id.

76 See id.

77 See Milt Freudenheim, Canadians See Rise in Drug Costs, N.Y. TMEs, Nov. 16, 1992, at D1.

$78 \mathrm{Id}$. 
patent regimes. But the one-country-at-a-time approach also had significant drawbacks for the industry, the most obvious of which was that it was inefficient. There are far too many countries with lucrative pharmaceutical markets to approach individually. If pharmaceutical companies' intellectual property was truly going to be protected on a global basis, some kind of comprehensive agreement would be necessary.

GATT was not the most obvious place for fashioning such an agreement. The existing international agreements on intellectual property, the Paris Convention on patents ${ }^{79}$ and the Berne Convention on copyrights, ${ }^{80}$ are administered by the United Nations-affiliated World Intellectual Property Organization ("WIPO"). ${ }^{81}$ Third World countries strongly favored WIPO negotiations over revision to international intellectual property obligations. ${ }^{82}$ They noted that the WIPO had traditionally handled such matters. ${ }^{83}$ Furthermore, Third World countries felt that they would exercise greater influence in WIPO negotiations than they would in GATT. ${ }^{84}$ The United States insisted, however, that the GATT Uruguay Round negotiations include intellectual property. ${ }^{85}$ This point continued to be disputed into the negotiations, with Chile' asserting as late as 1990 that intellectual property standards are themselves neutral and that all substantive proposals on intellectual property made in GATT should be forwarded to WIPO. ${ }^{86}$ Nonetheless, the U.S. insistence on confining the negotiations to GATT prevailed, and the WIPO alternative faded as the Uruguay Round negotiations

79 See Paris Convention for the Protection of Industrial Property, July 14, 1967, 828 U.N.T.S. 305, 21 U.S.T. 1583.

${ }^{80}$ See Berne Convention for the Protection of Literary and Artistic Works, July 1, 1967, 828 U.N.T.S. 22.

${ }^{81}$ See id. art. 1 (referencing the WIPO).

${ }^{82}$ See Craig Edgar, Note, Patenting Nature: GATT on a Hot Tin Roof, 34 WASHBURN L. J. 76, 98 n.54 (1994)

${ }^{83}$ See id.

84 See Jean M. Dettmann, GATT: An Opportunity for an Intellectual Property Rights Solution, 4 TRANSNAT'L LAW J. 347, 356 (1991) (explaining that in WIPO, each nation has a vote and Third World Countries outnumber developed countries, whereas GATT relies on a "consensus" framework giving developed countries more leverage).

${ }^{85}$ See Robert Weissman, Patent Plunder: TRIPping the Third World, MUlTiNATIONAL MONITOR, Nov. 1990, at 8.

${ }^{86}$ See id. at 9. 
continued into the $1990 \mathrm{~s}^{87}$ The United States also rejected out of hand a Third World proposal to negotiate separate agreements covering counterfeit goods and patents. ${ }^{88}$

Throughout the TRIPS negotiations, the United States maintained a firm stance; for an agreement to be reached, other countries would have to adjust to its position. ${ }^{89}$ That position, essentially calling for the world to adopt U.S.-style patent law, was developed largely by the pharmaceutical industry, according to the industry itself. The Intellectual Property Committee ("IPC") claimed to have "played a key advisory role, at USTR's request, in developing the official U.S. proposal on intellectual property that the U.S. government tabled before the GATT TRIPS working groups in October 1987." 90 The Committee added in its promotional materials that its "close relationship with USTR and Commerce has permitted the IPC to shape the U.S. proposals and negotiating positions during the course of the negotiations." "91

The overwhelming success of the pharmaceutical industry's GAT'T effort was highlighted in 1992. Ironically, this occurred even as the industry was threatening to oppose the TRIPS Agreement. The source of the industry's frustration was the proposal for a ten-year transition period for Third World nations to develop full-fledged strict patent regimes. ${ }^{92}$ The industry's

87 See id.

88 See id.

89 See GATT: U.S. Proposal on Intellectual Property Is Presented to GATT, Gets Mixed Reviews, 7 Int'I Trade Rep. (BNA) No. 14, at 680 (May 16, 1990) (detailing a United States proposal encouraged by other industrialized countries and criticized by Third World countries).

90 Weissman, supra note 85 , at 8 .

91 Id.

92 See, e.g., Harvey E. Bale, Jr., New GATT Draft Text is a Potential Step Backward for Intellectual Property Rights, LEGAI BACKGROUNDER, Mar. 6, 1992, at 12 , available in LEXIS, News Library, Arcnws File (criticizing the lenient nature of the transition rules).

This criticism of the TRIPS agreement often focuses on the various economic and non-economic harms purportedly caused by the continuing opportunity for international piracy over the ten-year transition period:

The December 20 TRIPS text, while containing a number of both positive and negative elements, is critically defective because it would: (1) allow at least another decade of theft of U.S. pharmaceutical and other innovations; (2) give pharmaceutical pirates in Argentina, Brazil, Thailand, Hungary, India, and other developing nations grounds for 
vociferous opposition to a ten-year transition period ${ }^{93}$ obscured how much it had won. It had completely seized control of the terms of the debate. The disputed issue was no longer whether the rest of the world should or would adopt strict patent rules, but when it would. Third World advocates of alternative patent policies had largely silenced their criticisms of the U.S. demands. Their silence reflected domestic political changes; a decision to make sacrifices in the TRIPS text in exchange for purported benefits elsewhere in GATT; and, critically, the fact that the global intellectual and political climate had changed, making it much harder to argue for alternative patent schemes than it had been ten years earlier.

\subsection{The Conceptual Offensive: Framing for Victory}

Relying on the studies it had funded over the years, the industry was able to gather an impressive set of data and arguments to make two powerful claims about the importance of patent protection. ${ }^{94}$ First, it contended that inadequate international intellectual property protection costs U.S. manufacturers billions of dollars in sales annually. ${ }^{95}$ No one estimated the cost to the drug industry at anywhere near those levels, but the figure was placed in the billions nonetheless. ${ }^{96}$ The ITC study estimated the cost to ten drug manufacturers to be almost two billion dollars in 1986, and pharmaceutical maker Merck estimated the

opposing early reforms that would stop piracy and encourage investment and innovation in these countries; and, (3) continue to foster for a decade the export from India, et al., of substandard and counterfeit medicines that seriously harm consumers and the environment of the Third World - a subject of growing attention by the World Health Organization ("WHO").

Id.

${ }_{93}$ This provision was eventually included in the final TRIPS Agreement. See infra note 156 and accompanying text.

${ }_{94}$ See Al Wyss, Patent Protection Winning New Round, CHEMICAL MARKETING REP., Mar. 19, 1990, at SR22 (citing many of the studies used by the industry).

95 A widely cited study (the "ITC study") by the International Trade Commission ( $" \mathrm{ITC}$ ") placed the cost between $\$ 43$ billion and $\$ 61$ billion for all intellectual property violations. This estimate included not only generic drugs, but copyright violations like software copying and trademark infringements such as Rolex watch imitations. See id.

${ }^{96}$ See id. 
cost to be six billion dollars annually for the entire industry. ${ }^{97}$ In an era of persistent and large U.S. trade deficits, these were numbers large enough to make policy makers take notice.

Second, the industry made an impressive set of arguments about the necessity of strong intellectual property protection in fostering economic development. ${ }^{98}$ It argued that respecting patent rights would actually benefit the Third World by encouraging foreign and domestic investment in research and by enabling high technology companies to engage in technology transfer with Third World nations."

But however convincing these arguments, it was not their merit which made it so difficult to defend genuine alternative approaches to patent policy by the early $1990 \mathrm{~s}^{100}$ Rather, that depended crucially on the ability of the pharmaceutical industry and its allies in the U.S. government ${ }^{101}$ to frame the debate on their terms.

\subsubsection{Rights Talk}

Characterizing patent protections as a kind of intellectual property "right" was a first step in setting the terms of debate. This characterization is of course not novel; patents, trademarks, and copyrights have long been viewed as intellectual property rights. ${ }^{102}$ This is evidenced, in part, by the common reference to intellectual property rights by the acronym "IPR." 103 Nor is the characterization, from a legal standpoint, startling or at all surprising. Lawyers commonly understand that the holders of government-authorized powers have "rights," without attaching any particular moral force to the term.

97 See id.

98 See, e.g., Richard T. Rapp \& Richard P. Rozek, Benefits and Costs of Intellectual Property Protection in Developing Countries, J. OF WORLD TRADE, Oct. 1990, at 75, 77-81 (discussing a study funded by a grant from the PMA).

99 See id.

100 See infra Section 6 for a critique of the second set of arguments.

101 The period of time involved here is expansive enough to include officials in the Reagan, Bush, and Clinton administrations.

102 See Robert Fredrico, Operation of the Patent Act of 1790, $18 \mathrm{~J}$. PAT. OFF. SOC. 237, 238 (1936) (consistently describing patents as a "right").

${ }_{103}$ See, e.g., Robert P. Merges, Comment, Of Property Rules, Coase, and Intellectual Property, 94 COLUM. L. REV. 2655, 2655 (1994) (referring consistently to "IPRs"). 
In the debate over international patent policy, however, the use of the term "right" exercised an important influence. As a preliminary matter, it is important to recognize that while "rights" may be commonplace in legal discourse, the allocation or recognition of a right may nonetheless privilege certain actions or relations. Characterizing something as a right tends to immunize it from challenge both in practice and in the realm of ideas. To transgress a right is to "violate" it, to commit a wrong. To define something as a right is to remove it, more or less, from political challenge. Even if it is not considered a "natural" right; in moral terms, a right is supposed to be somewhat inviolate.

While rights talk may have the general effect in legal discourse of elevating the defined conduct or relationship above politics, that effect was particularly strong in the case of patent policy. The vociferous insistence of industry and the U.S. government assumed a moral character. ${ }^{104}$ This was an especially notable accomplishment in light of the intangible nature of intellectual property. Additionally, intellectual property is more obviously a creation of the state than other sorts of property. Hence it intuitively enjoys less of a moral right than other property claims. At the practical level, one does not receive a patent until an invention is certified by the state as new, useful, and nonobvious. ${ }^{105}$ This makes it unusually clear that the state could choose not to grant the right at all. At the conceptual level, patent rights evaporate after a set period. ${ }^{106}$ Governments may grant patents for longer or shorter periods, on conditions, or not at all. The characterization of an inventor or producer's intellectual property interest as a "right" works to obscure the contingent nature of the patent. ${ }^{107}$

104 See infra Section 3.2.2.

105 See, e.g., 35 U.S.C. $\$ 101-103$ (1994) (prescribing conditions for patentability).

106 In part, this reflects the policy balancing embedded in the decision to grant patents at all. See supra note 7 and accompanying discussion.

${ }_{107}$ Put another way, imagine the debate was not about intellectual property rights, but about intellectual property grants (or licenses or privileges). That would cast the discussion in an entirely different light. If the government is granting something, it seems logical to permit the government to attach conditions to it. A grant is discretionary as well, suggesting the government has the power - and is morally entitled - to refuse to make the grant altogether. 


\subsubsection{Piracy}

The dominant and most aggressive metaphor of the debate was piracy. The pharmaceutical industry and the U.S. government labeled generic drug companies which copied pharmaceuticals patented in other countries "pirates." 108 They denounced countries that permitted drug copying as harboring pirates. ${ }^{109}$

The pharmaceutical industry did not invent this metaphor, which has been used for hundreds of years. ${ }^{110}$ But the pharmaceutical industry did use the metaphor more extensively, aggressively, and successfully than any before. It became a term with emotional content, rather than just descriptive purpose.

The piracy metaphor effectively changed a policy debate into an absolutist moral drama. Theft is simply wrong, and theft by violence is even worse. There is no room for a policy discussion about the merits of piracy, nor any space for compromise in the direction of pirates. Consider the stridency of C.L. Clemente, the vice president-general counsel of Pfizer:

Why is it that another government can base a policy of helping the consumers in their country to steal foreignowned technology?

If we went back to the days when countries engaged in piracy, wouldn't it have been ludicrous to say, 'Well, Brazil owes the United States a great deal of money, so we cannot stop their pirates from boarding our ships because, after all, they obtain a great deal of revenue from this, and gold and silver, et cetera.' Obviously, that's absurd. It's really not too different when we're talking about intellec-

108 See C.L. Clemente, A Pharmaceutical Industry Perspective, in INTELLECTUAL PROPERTY RIGHTS AND CAPITAL FORMATION IN THE NEXT DECADE 127, 132-33 (Charles E. Walker \& Mark A. Bloomfield eds., 1988).

109 See id. Some Third World development activists and their allies in industrialized countries reverse the metaphor by labeling pharmaceutical company attempts to patent genetic strains cultivated by Third World farmers and herbalists as "biopiracy." See Hope Shand, Patenting the Planet, MULTINATIONAL MONITOR, June 1994, at 9; see also infra Section 3.2.3. (discussing the author versus source distinction).

110 See, e.g., Evans v. Eaton 20 U.S. (7 Wheat.) 161, 163 (1822) (describing an alleged use of the Hopperboy, a flour manufacturing machine, as "pirating"). 
tual property; that kind of stealing is just as bad. ${ }^{111}$

Similarly, when the PMA voiced its opposition to a ten-year phase-in for the strict GATT patent requirements, association representatives decried the effort to provide a "long 'grace period' for piracy." 112

\subsubsection{Author Versus Source}

Professor James Boyle suggests another metaphor underlying the patent policy debate: the figure of the romantic author as inventor and creator, someone with a right to make a property claim because of the original contribution she has made to general knowledge. ${ }^{113}$ The PMA has not claimed for itself authority conferred by Shakespeare, but it is highly cognizant of the principle enunciated by Professor Boyle. In fact, in 1994, the PMA changed its name to the Pharmaceutical Research and Manufacturers of America. ${ }^{114}$ This critical move emphasizes the originality and unique contribution of member companies' research. The emphasis on their research efforts - as opposed to the "imitative" or pirating techniques 115 of their generic competitors - is a moral claim, a means to defend high drug prices in the United States and to justify the demand that other nations adopt U.S.-style patent laws. ${ }^{116}$ This distinction serves as the basis for the normative "author versus source" dichotomy that the PhMRA attempts to exploit.

Perhaps the most illuminating application of Professor Boyle's author versus source distinction is in the context of Third World biological resources patenting. Most of the world's biodiversity is located in the Third World, particularly in tropical and semi-

111 Clemente, supra note 109, at 132-33.

112 Bale, supra note 92 , at 12 .

${ }^{113}$ See James Boyle, $A$ Theory of Law and Information: Copyright, Spleens, Blackmail, and Insider Trading, 80 CAL. L. REV. 1413, 1510 (1992).

${ }^{114}$ See supra note 30.

115 See Gerald J. Mossinghoff, Research-Based Pharmaceutical Companies: The Need for Improved Patent Protection Worldwide, 2 J. OF L. \& TECH. 307, 307 (1987) ("There are two kinds of pharmaceutical companies: research-based companies and imitators that do not carry out substantial research on their own but profit from the fruits of the research of others.").

116 Whether the claim to originality is fully justified is addressed in the public versus private discussion, see infra section 3.2.4. 
tropical regions. ${ }^{117}$ Only a relatively small fraction of that biodiversity has been categorized and studied, and scientists are increasingly coming to believe that it may contain the ingredients for a wide array of life-saving medicines. ${ }^{118}$ Accordingly, multinational pharmaceutical corporations are increasingly surveying plant life in Third World regions to locate genes that can form the basis for new drugs. ${ }^{119}$ Although naturally occurring substances are not patentable, the pharmaceutical companies are able to synthesize chemical substances with mild alterations and patent them. ${ }^{120}$

The image of the adventurous pharmaceutical company explorer-genetic prospector superficially suggested by the corporate effort to survey Third World genetic resources is inaccurate. Company representatives do not wander into the rain forest jungle to collect samples. Instead, corporate botanists and anthropologists rely on Third World farmers and herbalists, especially from indigenous communities that make their home in or live off of the rain forest, to direct them to plants that they use in local medicines. ${ }^{121}$ Over centuries, these farmers and herbalists have identified, cultivated, bred, and protected the plant varieties. ${ }^{122}$ These informal innovations are not patentable, however, because they are not "new."123 More obviously, a Kayapo farmer in Brazil and a Sakai herbalist in Indonesia have no practical means to patent their innovations.

Permitting drug companies to patent company contributions, and the legal inability of the Third World innovators to patent their contributions, Boyle suggests, illustrates the power of the romantic author impulse in patent law. ${ }^{124}$

The chemical company's scientists fit the paradigm of

117 See Shayana Kadidal, Note, Plants, Poverty, and Pharmaceutical Patents, 103 YALE L. J. 223, 224 n.8 (1993).

118 See id. at 223 n.3.

119 See Klaus Basselmann, Plants and Politics: The International Legal Regime Concerning Biotechnology and Biodiversity, 7 COLO. J. INT'L ENVT. L. \& POL'Y 111, 117 (1996).

120 See Kadidal, supra note 118 , at $237-43$.

121 See Shand, supra note 110, at 10-11.

122 See id.

123 See id.

124 See Boyle, supra note 114, at 1529. 
authorship. The farmers are everything that authors should not be: their contribution comes from a community rather than an individual, tradition rather than an innovation, evolution rather than transformation. Guess who gets the intellectual property right? ${ }^{25}$

The Third World farmers and herbalists' contribution is thus denigrated. The author versus source metaphor condemns them as merely an adjunct of the source, the indigenous plants. ${ }^{126}$ It further shapes a substantial portion of patent allocations for the industry. ${ }^{127}$

Recognition of this reality undermines the pharmaceutical companies' moral claim to strict patent rules in every country. Furthermore, calling attention to the Third World's unacknowledged contribution to the development of pharmaceuticals also raises the possibility of alternative approaches to patent policy.

\subsubsection{Public Versus Private}

The public versus private distinction pervades patent law. ${ }^{128}$ Inventions already in the public domain cannot be patented, because they fail the novelty test. ${ }^{129}$ At the same time, one of the motivating rationales of the patent system is to bring knowledge from the private domain into the public by offering protections to private creators. ${ }^{130}$ Furthermore, one of the conceptual tensions in patent law is reflected in the determination of whether patents should be issued for inventions building on

125 Id.

126 See Shand, supra note 110, at 11.

127 See id. at 11 ("An estimated three-quarters of all plant-derived prescription drugs were discovered as a result of their prior use in indigenous medicine. The annual world market value of these medicines is estimated at $\$ 43$ billion ....").

${ }^{128}$ "[E]very dispute about property rights in information resolves itself into a dispute about whether the issue "is' in the public or the private realm." Boyle, supra note 114, at 1435 .

129 See, e.g., Kevin Rhodes, Comment, The Federal Circuit's Patent Nonobviousness Standards: Theoretical Perspectives on Recent Doctrinal Changes, 85 NW. U. L. REV. 1051, 1051 (1991) (citing provisions of U.S. patent law, including 35 U.S.C. \$ 102 (1988)).

${ }^{130}$ See J. Davidson Frame, National Commitment to Intellectual Property Protection: An Empirical Investigation, 2 J.L. \& TECH. 209, 210 (1987). 
information already in the public domain. ${ }^{131}$

What is defined as public and what is defined as private is thus an ultimate issue of patent law. It is in the pharmaceutical companies' interest to define the biological resources of the Third World as "the common heritage of mankind."132 That makes the resources public, and thus unpatentable. If the biological resources are not patentable, then Third World countries are basically unable to capture any of the wealth-producing benefits of their industrial development. ${ }^{133}$

The pharmaceutical industry, however, is far less generous in its understanding of the public domain with regard to industrialized countries. For example, the U.S. government spends billions annually on biomedical research. ${ }^{134}$ Thus, government-funded research often provides the platform for industry to conduct its own research. Furthermore, government-funded research often leads to the discovery of new drugs which are exclusively licensed to private companies, or sometimes slightly modified and patented. ${ }^{135}$ A generous conception of the "public" nature of

${ }^{131}$ For example, under a "labor theory of property rights" there is a strong incentive to accord patent protection to the development of a useful invention from a publicly known but undeveloped source. See John R. Thomas, The Question Concerning Patent Law and Pioneer Inventions, 10 HIGH TECH. L. J. 35, 78 (1995).

${ }_{132}$ See id. at 228 n.35 (discussing the origins of this phrase).

133 See id. at 224 ("Little or none of [the profits] go to the countries where these naturally occurring compounds were originally found."). Contrast this case to other sorts of resources, such as oil, where geographic location determines ownership.

134 The total federal allocation for research and development in fiscal year 1993 was $\$ 76$ billion. See Chris Lewis, Public Assets, Private Profits: Federal RED and Corporate Graft, MULTINATIONAL MONITOR, January/February 1993 , at 8 . That amount represented $46 \%$ of the total national expenditure, public and private, on research and development. See id.

135 See id. The quintessential example of this point is AZT, one of the few drugs available to relieve conditions associated with the Human Immunodeficiency Virus (" $\mathrm{HIV}^{\prime)}$ ) and resulting Acquired Immune Deficiency Syndrome (“AIDS"). AZT was developed in federal government laboratories. See id. Burroughs Wellcome, the British company which eventually acquired exclusive control over the drug, contributed little money to the drug's development. See $i d$. The company only became interested after the National Cancer Institute had identified AZT as an effective agent in curbing the advance of AIDS among HIV-positive patients. See id.

Consider also the remarkable findings of the Washington, D.C.-based Taxpayer Assets Project ("TAP"):

For example, in a study presented in February 1993, TAP 
drugs developed with a large dose of government funding could undermine the pharmaceutical companies' patent claims.

There is no escaping the private-public distinction in patent and intellectual property law. Certainly the pharmaceutical industry understands, at least implicitly, how to manipulate the distinction to its advantage. Consciously focusing on how this distinction plays a key role in the allocation of intellectual property "rights" should highlight the alternatives available to policy makers in providing either more or fewer protections to different parties.

examined the federal government's role in the development of all FDA approved cancer [fighting] drugs that were discovered since 1955, and found that 34 of the 37 cancer [fighting] drugs were developed with significant federal support.

Earlier this year, TAP presented a study of all "priority" drugs approved by the FDA from 1987 to 1991 . During this 5 year period the FDA issued 2,270 drug approvals, but most were for generic drugs or new combinations of existing compounds. Only 117 of the new drug approvals involved so called "New Molecular Entities" (NMEs) ... drugs distinctly different in composition from drugs al ready on the market. Of these 117 NMEs, only 30 were judged by the FDA to be drugs that were used in the treatment of severe illnesses or to represent a substantial gain in therapeutic value.

Of these 30 "important" new drugs approved by the FDA, 15 benefited from significant funding by the U.S. government. When one considers the country where the drug was discovered the government's role is even more important. Seventeen of the "important" new drugs were discovered in the U.S. Of these drugs, 12 were developed with significant government funding - that is, $71 \%$ were developed with significant government funding.

The U.S. government spends an enormous amount of money on health care research, and this investment has been very productive. On the basis of our research, we have concluded that while the private sector's R\&D investments are also large, they tend to be directed at the lower risk ventures, and often are directed at the development of so called "me too" drugs, which do not represent significant improvements in therapy, but rather are marginally different methods of treating illnesses which represent large markets, measured by the companies in the number of dollars they will receive from consumers.

James P. Love, Pharmaceutical Drug Pricing: Hearings Before the Senate Committee on Government Affairs, FED. DOCUMENT CLEARING HOUSE, July 27, 1994, available in LEXIS, News Library, Arcnws File (citations omitted). 


\section{GATT AND THE TRIPS AGREEMENT}

\subsection{The WTO and the Promise of Forceful GATT Enforcement}

In April 1994, the Uruguay Round GATT negotiations concluded. ${ }^{136}$ In December 1994, the U.S. Senate approved the new GAT'T, paving the way for the agreement to take effect in 1995. ${ }^{137}$

The Uruguay Round creates a new World Trade Organization to administer and enforce the GATT agreements. ${ }^{138}$ Under the WTO, GATT member countries will be severely constrained from violating the terms of any of the Uruguay Round agreements, including the TRIPS Agreement. ${ }^{139}$

The WTO includes a powerful new dispute resolution machinery to resolve disputes between GATT members about a nation's adherence to the terms of the Uruguay Round agreements. ${ }^{140}$ Three-person dispute settlement panels, composed of trade experts ${ }^{141}$ who meet in secret, ${ }^{142}$ issue decisions on whether a country's actions, laws, or regulations violate the terms of a Uruguay Round agreement. ${ }^{143}$ Decisions of the dispute settlement panels can be appealed to a standing seven-member Appellate Body. ${ }^{144}$

136 See generally JEFFREY J. SCHOTT \& JOHANNA W. BURMAN, THE URUGUAY ROUND: AN ASSESSMENT (1994) (detailing the long and complex process of negotiations involved in the Uruguay Round).

137 See H.R. 5110, 103d Cong. (1994) (enacted) (evidencing the final ratification of the Uruguay Round); see also Helene Cooper \& John Harwood, Major Shifts in Trade are Ensured as GATT Wins Key Senate Vote, WALL ST. J., Dec. 2, 1994, at A12 (reporting on the Senate's approval of GATT).

138 See Final Act para. 1.

139 See generally Reitz, supra note 41 (discussing the new enforcement procedures of the Uruguay Round); see also Understanding on Rules and Procedures Governing the Settlement of Disputes [hereinafter Dispute Settlement Understanding], Apr. 15, 1994, Annex 2, LEGAL INSTRUMENTS RESULTS OF THE URUGUAY ROUND vol. 31, 33 I.L.M. 1226, app. 1 (specifically listing the TRIPS agreement as a "covered agreement" under the understanding).

140 See Dispute Settlement Understanding, art. I.

141 See id. art. 8, para. 1.

142 See id. art. 2.

143 See id. art. 3.

144 See id. art. 17 (referring to the Appellate Body); see also Reitz, supra note 41, at 582-84 (discussing the significance of the Appellate Body). Although the Appellate Body consists of seven members, only three members actually hear 
Dispute panel decisions, or Appellate Body decisions in the instance of an appealed case, are final unless every WTO Member nation - including the complaining country - agrees to reject the panel or Appellate Body's recommendation. ${ }^{145}$ This "reverse consensus" requirement turns past GATT practice on its head by eliminating the de facto veto which member nations maintained under the old GATT dispute settlement process ${ }^{146}$ and gives every WTO signatory the unilateral power to force adoption of any panel or Appellate Body decision. ${ }^{147}$

If the losing party declines to revise its laws to make them consistent with the panel's interpretation of WTO rules, then it must either agree to pay perpetual compensation negotiated with the prevailing party or face trade sanctions imposed by the prevailing party. ${ }^{148}$ Trade sanctions are to be of an amount equivalent to the value of market access lost by the prevailing party due to the practices found WTO-illegal, but may be levied against any industrial sector. ${ }^{19}$

This complicated dispute settlement mechanism is likely to apply severe pressure on countries to alter patent or other laws found by a dispute settlement panel to be WTO-illegal. Potential sanctions are likely to be large, especially from the viewpoint of poor Third World nations. The threat of "cross-sectoral retaliation" - the imposition of sanctions against a different economic sector than the one in which the WTO-illegal law exists ${ }^{150}-$ will be particularly coercive. It raises the possibility that domestic lobbies in unrelated industries would emerge to oppose laws or

any given appeal. See Dispute Settlement Understanding art. 17.

${ }_{145}$ See id. art. 16, para. 4. This entire body is referred to as the Dispute Settlement Body ("DSB"). See id.

146 See G. Richard Shell, The Trade Stakeholders Model and Participation by Nonstate Parties in the World Trade Organization, 17 U. PA. J. INT'L ECON. L. 359, 363-65 (1996) (discussing the "de facto" veto power that the losing party enjoyed under the previous system).

147 See Reitz, supra note 41, at 585-86 (discussing this "ingenious" method of international enforcement).

148 See Dispute Settlement Understanding art. 22, para. 2.

149 See id. art. 22, para 4.

${ }^{150}$ Cross-sectoral retaliation is expressly permitted in the Dispute Settlement Understanding. See id. art. 22, para. 3(c). For example, if the United States successfully challenges Thailand's patent law, and Thailand refuses to repeal the law, the United States could levy sanctions not just on the Thai pharmaceutical industry, but on Thai textile imports. See id. 
regulations found WTO-illegal. ${ }^{151}$ These lobbies would represent industries that would feel the pain of WTO-authorized sanctions but not reap the benefits of the laws giving rise to sanctions. ${ }^{152}$ Finally, WTO decisions are likely to give countries the political legitimacy to impose more trade sanctions. Under the prior regime, even the United States, which in the last fifteen years has been rhetorically belligerent about imposing sanctions against violators of international trade rules, has been significantly constrained from doing so. ${ }^{153}$ This is part of the reason why U.S. trade negotiators sought to strengthen the GATT dispute settlement procedure and why they pointed to the final dispute settlement agreement as a victory. ${ }^{154}$ The bottom line: it is going to be far more difficult for countries - especially less powerful countries - to maintain domestic laws in contravention of GATT rules than it has been previously.

\subsection{Patent Policy Alternatives Under TRIPS}

Backed by its strong enforcement mechanism, the new GATT unquestionably limits the patent policy options of national governments in the Third World and the industrialized world alike. ${ }^{155}$ The final TRIPS Agreement ultimately did mandate adoption of U.S.-style patent laws - or so it seems at first glance. ${ }^{156}$ However, there are a number of exceptions and loopholes which leave countries with substantial leeway, though not as much as they had before the TRIPS Agreement, to

151 Some commentators have even speculated about the effects that private lobbies could have on the WTO process itself. See, e.g., Steve Charnovitz, Participation of Nongovernmental Organizations in the World Trade Organization, 17 U. PA. J. INT'L ECON. L. 331 (1996).

${ }^{152}$ For example, assume a WTO panel determined that French subsidies to grape growers were violations of GATT principles in a complaint brought by the United States. The United States, consistent with new GATT principles, could impose sanctions on cheese imports from France. Cheese exporters in France would obviously lobby against the grape growing subsidies since they receive no benefit but would be damaged by the sanctions.

153 See Overview of the Results of the Uruguay Round: Hearings Before the Senate Comm. on Commerce, Science, and Transp., 103d Cong. 9 (1995) (statement of Hon. Michael Kantor, United States Trade Representative).

154 See id.

155 Article 66 of the TRIPS agreement provides for a 10-year transition period for least developed countries. They will not have to comply with the terms of the agreement until 2005. See TRIPS Agreement art. 66.

156 See id. 
experiment with different patent schemes.

Section 5 of the TRIPS Agreement covers patent rules in Section 5, the core of which is Article 27 and 28. ${ }^{157}$ Article 27 defines patentable subject matter. ${ }^{158}$ It provides, "[p]atents shall be available for any inventions, whether products or processes, in all fields of technology, provided that they are new, involve an inventive step and are capable of industrial application."159 Article 27 also requires that patent rights be conferred "without discrimination as to place of invention, field of technology, or whether the products are imported or locally produced." 160 Article 28, Paragraph 1, defines the rights conferred by a patent:

A patent shall confer on its owner the following exclusive rights:

(a) where the subject matter of a patent is a product, to prevent third parties not having his consent from the acts of: making, using, offering for sale, selling, or importing for these purposes that product;

(b) where the subject matter of a patent is a process, to prevent third parties not having his consent from the act of using the process, and from the acts of: using, offering for sale, selling, or importing for these purposes at least the product obtained directly by that process. ${ }^{161}$

On their face, Articles 27 and 28 appear to preclude most of the alternatives to strict patent regimes implemented or considered by Third World countries in the last several decades. The

157 See id. arts. 27-28.

158 See id. art. 27.

159 Id. art. 27, para. 1. A footnote to the article establishes that "the terms 'inventive step' and 'capable of industrial application' may be deemed by a Member to be synonymous with the terms 'non-obvious' and 'useful' respectively." Id. n.5.

${ }^{160} I d$. art. 27.

161 Id. art. 28, para. 1 (citation omitted). Article 29 establishes the reciprocal conditions on patent applicants: they must "disclose their invention in a manner sufficiently clear and complete for the invention to be carried out by a person skilled in the art ... Id. art. 29, para. 1. 
requirement that signatories grant patents for "any inventions ... in all fields of technology" that are new, useful and non-obvious clearly encompasses pharmaceuticals, making the strategy of excluding pharmaceuticals from patent protection altogether GATT-illegal. The Agreement specifically requires coverage of both products and processes, precluding countries from establishing regimes which recognize only one or the other. Article 33 requires that patent protection be afforded for twenty years from the date of filing, preventing countries from tinkering with the length of patents in order to calibrate the longitudinal strength of the monopoly they confer. ${ }^{162}$ Article 28's strict limitations on third parties' use of patents in the absence of the patent holders' consent seems to eliminate the possibility of compulsory licensing schemes. ${ }^{163}$ Article 27's requirement that patent rights be enjoyable without regard to whether products are imported or locally produced precludes work-the-patent requirements. ${ }^{164}$

A comprehensive reading reveals, however, that special tax schemes - as long as they are nondiscriminatory between domestic and foreign producers - and price controls - again, so long as they are nondiscriminatory - are not precluded by the core elements of the Agreement. ${ }^{165}$

Despite apparent narrowing of the patent policy alternatives open to Third World countries, the TRIPS Agreement also contains a number of exceptions arguably reopening opportunities seemingly foreclosed by the provisions discussed above. There are three relevant exceptions explicitly stated in the TRIPS Agree-

162 See id. art. 33.

163 See id. art. 28. Indeed the terms are so all-inclusive that some generic drug makers have complained that it will prevent all development of production processes for pharmaceuticals going off patent until after the patent expires, effectively adding years to the length of time over which the patent holder will maintain a monopoly over the patented product. See Generic Drug Industry Under Pressure on Several Fronts, PHARMACEUTICAL BUS. NEWS, June 26, 1992, at 4 (Article 28 "will add about five years of effective patent life" (two years of product development and three years for regulatory approval)" according to Wayne Schnarr, research director of the Canadian Drug Manufacturers Association).

${ }^{164}$ See supra section 2.2.5. (discussing work-the-patent requirements). Obviously, a patent that is invalid unless developed or used in the domestic countries does not fulfill this non-discriminatory requirement.

165 See generally TRIPS Agreement. 
ment, ${ }^{166}$ and one implied by the structure of the Agreement, which should serve to preserve pharmaceutical patent policy alternatives available to Third World policy makers.

The first exception is contained in Article 27. It permits exclusion from patentability where necessary to protect public health and the environment. ${ }^{167}$ Article 30 provides the second exception, permitting members to provide limited exceptions to patent exclusivity, contingent upon a showing that the interests of the patent owner are not unreasonably infringed upon. ${ }^{168}$ Article 31 provides the third exception; it explicitly permits compulsory licensing subject to a long list of restrictions. ${ }^{169} \mathrm{~A}$ fourth exception, implicit in the Agreement's allowance of price controls, ${ }^{170}$ effectively allows a government to impose price controls or nondiscriminatory taxes and condition their waiver on a patent holder's willingness to license its product or process on a non-exclusive basis.

\subsubsection{The Public Health Protection Provision}

As referenced above, the TRIPS agreement contains a public health exception:

Members may exclude from patentability inventions, the prevention within their territory of the commercial exploitation of which is necessary to protect ordre public or morality, including to protect human, animal or plant life or health or to avoid serious prejudice to the environment, provided that such exclusion is not made merely because the exploitation is prohibited by domestic law. ${ }^{171}$

By its terms, the public health exception permits countries to

${ }^{166}$ A fourth, very important exception is not relevant to the discussion here. The TRIPS agreement also provides that "diagnostic, therapeutic and surgical methods for treatment of animals and humans," as well as "plants and animals other than microorganisms" may be excluded from patentability. Id. art. 27, para. 3 .

167 See id. art. 27 , para. 2.

168 See id. art. 30.

169 See id. art. 31.

170 See id. art. 40, para. 2.

171 Id. art. 27, para. 2. 
deny patents altogether where they have a legitimate health or environmental reason to prevent the commercial exploitation of an invention. Assuming the reason is legitimate, the exception will permit a country to deny a patent to a particular drug or to all drugs.

However, the provision requires the denial of patentability to be linked to a denial of commercial exploitation of the invention. ${ }^{172}$ This requirement substantially limits the scope of the public health provision. It does not allow for either a no-patent system where private corporations are free to produce and sell generic drugs for profit or for compulsory licensing schemes. Both of these systems implicitly contemplate commercial exploitation. Nor would it allow for shorter patent terms, since although they are designed to speed generic production of drugs and thus lower overall drug prices, they too are based on expectations of future commercial exploitation. ${ }^{173}$

Moreover, the public health provision offers no support to work-the-patent requirements, which are designed to encourage foreign investment and technology transfer. They are not necessarily directly targeted at public health goals.

Still, the public health provision does offer at least one important alternative to Third World countries. Capitalizing on the provision, they could deny patentability for one or all drugs and produce and distribute them non-commercially through a state-owned marketing board, quasi-state entity, single non-profit manufacturer, or system of non-profit manufacturers. Especially for countries pursuing Essential Drugs programs, ${ }^{174}$ this govern-

172 See id.

173 A further consideration questions whether compulsory licensing schemes or shorter terms would qualify under the public health provision for yet another reason - the provision speaks of excluding from patentability, not conditioning patentability. An interesting argument could be formulated that the exclusion of patentability necessarily permits the conditioning of patentability - a kind of hierarchy of powers argument. Such an argument would be irrelevant, however, in view of the preclusions presented by principles set forth in the main text above.

174 Essential Drugs programs rely on a government registry of a core group of essential drugs, which are made available in generic form at low prices. See, e.g., John E.S. Parker, Pharmaceuticals and Third World Concerns: The Lall Report and the Otago Study, in THE INTERNATIONAL SUPPLY OF MEDICINES: IMPLICATIONS OF U.S. REGULATORY REFORM 135, 139 (Robert B. Helms ed., 1980) (giving an example of the Indian essential drug policy). Mild Essential Drugs programs can co-exist with for-profit sales of drugs. More aggressive 
ment/non-profit option may be attractive. In order to adopt a policy of domestic, non-commercial exploitation, however, a GAT'T signatory nation would have to overcome another hurdle: the requirement that its actions be "necessary."

In recent years, GATT dispute settlement panels have created a substantial jurisprudence interpreting GATT Article XX, which provides for general exceptions to GATT rules. ${ }^{175}$ In the WTO adjudicatory system, there is no formal system of stare decisis, but relevant precedent nonetheless exerts strong persuasive influence on current decisions. ${ }^{176}$ The interpretation of the TRIPS Article 27 is likely to be shaped in significant part by the doctrines developed in prior GATT Article XX decisions, and analyzing the scope of the TRIPS public health provision requires a review of those decisions. ${ }^{177}$

The first critical Article XX decision involved a European Economic Community challenge to Section 337 of the U.S. Trade Act of $1930 .{ }^{178}$ That act established an optional procedure for U.S. patent holders to bring legal action against foreign persons or corporations allegedly exporting to the United States products

versions may involve a ban altogether on sales of non-listed drugs. See DIANNA MELROSE, BITTER PILLS: MEDICINES AND THE THIRD WORLD POOR 148 (1982). The listed drugs are often produced by domestic generic makers, but could be produced by government or non-profit entities. See id. at 153.

175 See General Agreement on Tariffs and Trade, Oct. 30, 1947, 61 Stat. A11, T.I.A.S. 1700, 55 U.N.T.S. 194, art. XX(b) [hereinafter GATT]. The provision states:

Subject to the requirement that such measures are not applied in a manner which would constitute a means of arbitrary or unjustifiable discrimination between countries where the same conditions prevail, or a disguised restriction on international trade, nothing in this Agreement shall be construed to prevent the adoption or enforcement by any contracting party of measures: .... (b) necessary to protect human, animal or plant life or health ....

Id.; see also Reitz, supra note 41, at $569 \mathrm{n} .63$ (discussing a case between the United States and Canada concerning resolution of Article XX issues).

${ }^{176}$ See Pierre Pescatore, Drafting and Analyzing Decisions on Dispute Settlement, in 1 PIERRE PESCATORE, ET AL., HANDBOOK OF WTO/GATT DISPUTE SETTLEMENT pt. 2, at 6, 23 (6th ed. 1995) (discussing the proper role of stare decisis in past and future GATT decisions).

177 See id.

178 See Report of the Panel on United States: Section 337 of the Tariff Act of 1930, Nov. 7, 1989, GATT B.I.S.D. (36th Supp.) at 345-46 (1990) [hereinafter Section 337 Panel Report]. 
which infringed their patents. ${ }^{179}$ While a purely domestic dispute over patent infringement would be heard in a federal district court, the optional special procedure concerning alleged foreign infringers involved a quasi-judicial hearing before an administrative law judge of the U.S. International Trade Commission. ${ }^{180}$ This hearing varied in a variety of ways from federal district court proceedings. ${ }^{181}$

The then-EEC attacked the procedures as a discriminatory violation of GATT Article III, ${ }^{182}$ which requires equal national treatment of imported goods. ${ }^{183}$ The United States defended the parallel ITC proceedings on several grounds. One of these was Article XX(d), permitting exceptions to GATT rules where "necessary to secure compliance with laws or regulations which are not inconsistent with the provisions of this Agreement, including ... the protection of patents." ${ }^{\prime 184}$ The United States argued that the parallel enforcement procedure was necessary to provide quick resolution and adequate sanctions against foreign infringers who could not be satisfactorily targeted through traditional civil remedies. ${ }^{185}$ The GATT dispute resolution panel rejected the U.S. argument with logic that has framed subsequent Article XX cases. ${ }^{186}$ First, the panel concluded that Article XX provided exceptions to the general GATT rules, and that panels should first analyze challenged practices for consistency with general GATT rules. ${ }^{187}$ Article XX analysis should ensue after a determination that certain conduct was a violation. ${ }^{188}$ This conclusion establishes that "Article XX(d) thus provides for a limited and conditional exception from obligations under other provisions." ${ }^{189}$ In other words, Article XX should

179 See id. at 350.

180 See id.

181 See id. at 351. Domestic patent holders alleging foreign infringement maintained the option of filing their case in federal district court. See id.

182 See GATT Art. III.

183 See Section 337 Panel Report, supra note 179, at 354.

184 GATT art. XX.

185 See Section 337 Panel Report, supra note 179, at 375.

186 See id. at 395.

187 See id. at 345 ("The Panel noted that Article XX is entitled 'General Exceptions' ....").

${ }_{188}$ See id.

189 Id. at 385. 
be treated as a disfavored provision, with a special burden placed on countries invoking it as a defense.

Second, and building on the first point, the Panel placed great weight on the term "necessary" in Article XX:

It was clear to the Panel that a contracting party cannot justify a measure inconsistent with another GATT provision as 'necessary' in terms of Article XX(d) if an alternative measure which it could reasonably be expected to employ and which is not inconsistent with other GATT provisions is available to it. By the same token, in cases where a measure consistent with other GATT provisions is not reasonably available, a contracting party is bound to use, among the measures reasonably available to it, that which entails the least degree of inconsistency with other GATT provisions. ${ }^{190}$

Henceforth, the "least-trade-restrictive" alternative test has been used. It is a very intrusive test in terms of impingement on national sovereignty, and one destined to become a major source of contention in the U.S. debate over the Uruguay Round agreements. ${ }^{191}$ It also seems clear that it is still part of GATT/WTO jurisprudence. ${ }^{192}$ stating:

190 Id. at 392-93. The Panel sought to limit the sweep of its ruling by

The Panel wished to make it clear that this [the imposition of the least-trade-restrictive test] does not mean that a contracting party could be asked to change its substantive law or its desired level of enforcement of that law, provided that such law and such level of enforcement are the same for imported and domestically produced products.

Id. at 393. Thus the disputed principle in the Section 337 case was that of nondiscrimination, not the substance of U.S. patent law.

191 The debate concerning GATT's impacts on U.S. sovereignty was particularly potent when the U.S. Senate considered ratification of the Uruguay Round. See Leonard Bierman, et al., The General Agreement on Tariffs and Trade: World Trade from a Market Perspective, 17 U. PA. J. INT'L ECON. L. 821, 825 (1996).

192 On January 17, 1996, the first panel decision rendered under the new WTO machinery was produced. See Bhushan Bahree, WTO Panel Rules Against U.S. in Dispute Over Gasoline Norms, WALL ST. J., Jan. 18, 1996, at A11. This panel decision also relied on the "least-trade-restrictive" standard. See Office of the United States Trade Representative, Panel Decision: Venezuela, Brazil, 
Third, and again reflecting its disfavor for Article XX based defenses, the Panel determined that it was not enough for a country to justify its entire challenged scheme as necessary. ${ }^{193}$ "In the view of the Panel, what has to be justified as 'necessary' under Article XX(d) is each of the inconsistencies with another GATT article found to exist ...."194

The Section 337 case was an Article XX(d) case, involving a measure purportedly necessary to enforce domestic laws. The interpretive conclusions of the Section 337 Panel arguably did not apply to Article XX(b) concerning the protection of human, animal or plant life and health.

The possibility of applying distinct standards to Articles XX(d) and XX(b) was rejected, however, in 1990, exactly one year after the Section 337 case, in the Thai Tobacco case. ${ }^{195}$ The United States sought to challenge Thailand's de facto ban on the importation of foreign tobacco. ${ }^{196}$ Its tobacco excise system authorized higher taxes on foreign-made cigarettes in the event they were imported. ${ }^{197}$ It also included various tobacco industry regulations, including a ban on tobacco advertising, that the United States alleged to be discriminatory practices in violation of GATT's general prohibition on quantitative restrictions of imports as well as the Agreement's requirement of national treatment. ${ }^{198}$ The Panel determined that the Thai practices did violate the referenced GATT provisions, and then considered whether the Thai practices could be justified as public health measures under Article XX(b). ${ }^{199}$

Most important in terms of establishing persuasive precedent, the Thai Tobacco Panel imported the Article XX(d) analysis from the Section 337 case into Article $\mathrm{XX}(\mathrm{b})$ analysis. Citing and quoting the Section 337 case, the panel concluded that it "could

United States on the Rule Issued by the Environmental Protection Agency on 15 December 1993, Jan. 17, 1996, available in WESTLAW, GATT Database.

193 See Section 337 Panel Report, supra note 179, at 393.

194 Id. at 393 (emphasis added).

195 See Report of the Panel on Thailand: Restrictions on Importation of and Internal Taxes on Cigarettes, Nov. 7, 1990, GATT B.I.S.D. (37th Supp.) at 200 (1990) [hereinafter Thailand Tobacco Panel Report].

196 See id. at 204.

197 See id. at 203.

198 See id. at 211-12.

199 See id. at 221-22. 
see no reason why under Article XX the meaning of the term 'necessary' under paragraph (d) should not be the same as in paragraph (b)."200 The Panel proceeded to adopt the Section 337 least-trade-restrictive-alternative test:

The Panel concluded from the above that the import restrictions imposed by Thailand could be considered to be 'necessary' in terms of Article XX(b) only if there were no alternative measure consistent with the General Agreement, or less inconsistent with it, which Thailand could reasonably be expected to employ to achieve its health policy objectives. ${ }^{201}$

The Panel rejected Thailand's argument that its restriction of foreign tobacco imports and its conferral of a tobacco marketing monopoly on a state company were "necessary" to control the domestic supply of the public health menace of tobacco and to prevent the importation of foreign cigarettes which contained extra dangerous additives. ${ }^{202}$ Education campaigns, bans on advertising and labeling requirements could all serve those goals in a less restrictive manner, the Panel reasoned. ${ }^{203}$ It accepted Thailand's claim that a nondiscriminatory ban on advertising did not violate national treatment requirements; and, the Panel concluded, even if it accepted the U.S. argument that the maintenance of an advertising ban in the immediate aftermath of a prior state monopoly on tobacco would discriminate against foreign producers whose brand names were relatively unknown, such discriminatory effect would be justified under Article XX(b) ${ }^{204}$

A subsequent panel again adopted a narrow reading of Article XX(b) in a 1991 decision condemning U.S. restrictions on imports of tuna not caught by dolphin-friendly methods. ${ }^{205}$ The Tuna-

${ }^{200} I d$. at 223.

201

Id.

${ }^{202}$ See id. at 226.

${ }^{203}$ See id. at 224.

204 See id.

${ }^{205}$ See Report of the Panel on United States: Restrictions on Imports of Tuna, Aug. 16, 1991, GATT B.I.S.D. (39th Supp.) at 155 (1993) [hereinafter Tuna-Dolphin Panel Report]. Because of the political controversy generated by the Panel report - a controversy which threatened support for the North 
Dolphin panel reiterated that Article XX permitted measures inconsistent with GATT only "to pursue overriding public policy goals to the extent that such inconsistencies were unavoidable." ${ }^{\text {206 }}$ The Panel reasoned that rather than imposing import restrictions, the United States should have sought to negotiate international cooperative arrangements. ${ }^{207}$ It also concluded that the nature of the U.S. import restriction - which pegged the permissible dolphin kill of foreign tuna exporters to the number actually killed by U.S. tuna fishers (allowing the foreign fishers a kill rate 1.25 times that of the U.S. fishers - was not consistent with an Article XX(b) effort to protect animal health. ${ }^{208}$

If the Article XX(b) decisions are to stand as precedent for Article 27, then a country seeking to invoke Article 27 would have to be prepared to argue that there was no means less inconsistent with the TRIPS Agreement available to achieve its public health goals of providing affordable essential drugs to its population. There should be little difficulty in demonstrating the public health importance of providing essential drugs at an affordable price. There is ample research showing the importance of access to affordable drugs, and the WHO is a strong endorser of Essential Drugs programs, a fact a WTO panel is likely to note and defer to. ${ }^{209}$ But a government would also have to show that no less inconsistent measure existing to accomplish this end. A challenging party may argue that government subsidies of drugs would accomplish the purpose, but given the potential cost of a subsidy program, such an alternative would not be reasonably available. Additionally, WTO panels cannot allow the subsidy argument to defeat public health programs, because it would swallow the entire public health provision of the TRIPS and the GATT. For example, in the Thai tobacco case, given the foreign company name recognition disadvantage, it would have been less inconsistent with GATT principles for Thailand not to ban advertising but to pay foreign tobacco companies not to advertise.

American Free Trade Agreement and the Uruguay Round - the GATT signatory parties did not adopt the report. See id.

206 Id. at 199.

207 See id. at 199-200.

${ }^{208}$ See id.

${ }^{209}$ Cf. Thai Tobacco Panel Report, supra note 196, at 216 (asking for and relying on opinions of WHO on health-related matters). 
No one could reasonably propose such a standard. A more effective challenge to the non-commercial exploitation of drugs would be a claim that price controls would be less restrictive. ${ }^{210}$

Another viable approach is available for a country defending a non-commercial exploitation policy from a least-trade-restrictive challenge. Specifically, a country could argue that the Article XX jurisprudence, despite the similarity in language and purpose, does not apply to Article 27. The development of the least-traderestrictive test in the Article XX context was rooted in a conception of the Article as providing exceptions which were limited and conditional. ${ }^{211}$ In contrast, Article 27, paragraph 2, is not an exception; it is included in one of the core provisions of section 5 , and it is part of the very definition of patentable subject matter. ${ }^{212}$ Thus the term "necessary" in Article 27 should not be given the intrusive interpretation it has been in Article XX GATT Panel decisions. A less stringent reading of "necessary" something closer to important, and with little or no attention to available alternatives ${ }^{213}$ - is more appropriate in this context. ${ }^{214}$ Under this more deferential standard, the defending country would make the same arguments, and they would be nearly sure-fire winners.

210 Indeed, if a patent holder were to agree to provide the desired drug at marginal cost or below, this option should satisfy the government - at least insofar as it is motivated by legitimate public health concerns. Even while pursuing a non-commercial exploitation strategy, a government could hope to build up domestic technological know-how. But while this would be a worthy goal, it would not be cognizable as a legitimate one for Article 27 purposes.

211 See supra note 190 and accompanying text.

212 See TRIPS Agreement art. 27, para. 2.

213 Or perhaps alternatives should be considered, but so should the political, institutional and fiscal impediments to adopting those alternatives - a set of factors GATT/WTO panels have heretofore refused to consider.

${ }^{214}$ This word [necessary] must be considered in the connection in which it is used, as it is a word susceptible of various meanings. It may import absolute physical necessity or inevitability, or it may import that which is only convenient, useful, appropriate, suitable, proper, or conducive to the end sought. It is an adjective expressing degrees, and may express mere convenience or that which is indispensable or an absolute physical necessity.

BLACK'S LAW DICTIONARY 1029 (6th ed. 1990). 


\subsubsection{Article 30: Exceptions to Rights Conferred}

TRIPS Article 30 potentially provides for very broad exceptions to the patent requirements of the Agreement:

Members may provide limited exceptions to the exclusive rights conferred by a patent, provided that such exceptions do not unreasonably conflict with a normal exploitation of the patent and do not unreasonably prejudice the legitimate interests of the patent owner, taking account of the legitimate interests of third parties. $^{215}$

Unlike Article XX of the GATT or Article 27, paragraph 2, of the TRIPS Agreement, Article 30 does not limit the purposes for which a country may make exceptions to the Agreement. ${ }^{216}$ Both public health purposes and a desire to promote local industry are legitimate Article 30 purposes. This would seem to authorize countries to undertake any of the range of patent policy options.

However, although Article 30 does not condition exceptions on national purpose, it does impose conditions on the right to make exceptions to the overall Agreement. ${ }^{217}$ These conditions are logical, because there is no evidence that Article 30 was intended as an all-purpose opt-out from TRIPS patent rules. The Article specifies three limitations. First, exceptions must be "limited." 218 Second, the exceptions cannot "unreasonably conflict with a normal exploitation of the patent."219 Third, the exception must not "unreasonably prejudice the legitimate interests of the patent owner."220

Quite obviously, none of these limitations are self-defining. Whether they allow or preclude various patent policy alternatives will turn on WTO panel interpretations of their meaning. The

\footnotetext{
215 TRIPS Agreement art. 30.

216 See id.

217 See id.

218 See id.

219 Id.

$220 \mathrm{Id}$.
} 
argument here is that these limitations should reasonably be interpreted to preserve a broad range of exceptions under Article 30 , and hence a broad range of pharmaceutical patent policy alternatives for Third World nations.

The first limitation on the Article 30 mandates that any exceptions must be limited. ${ }^{221}$ A strong case can be made that the meaning of "limited" is defined within the Article, by the subsequent "provided that such exceptions ..." language. ${ }^{222}$ In other words, the subsequent, more precise conditions describe what "limited" means in this precise context. The counterinterpretation would hold that such a reading makes "limited" superfluous, that it is intended to have independent force. In support of this counterinterpretation, a country challenging a Third World patent law could argue that Article 30 explicitly provides for exceptions, and one of the teachings of the Article XX GATT Panel jurisprudence is that exceptions are to be interpreted narrowly so as to preserve the broad integrity of the core Agreement. ${ }^{223}$ This argument carries some weight, but is not decisive, because Article 30 does provide a potential internal definition of "limited," while Article XX contains no such definition of "necessary." 224 The merits of these arguments appear about even.

Assume that the challenging country wins on this point, and "limited" should be interpreted to mean something more than the subsequent conditions in Article 30. "Limited" is still a term that restricts scope, but to an indeterminate degree. It is not at all apparent what sort of principled, substantive content can be given to the term other than those of the subsequent conditions. If "limited" is to have independent meaning, it must be that the Article 30 exception is not meant to be used to defeat the TRIPS Agreement on patents altogether. And at this level, every patent policy option discussed in the paper survives, because they are "limited" to the case of pharmaceuticals. They do not contemplate restrictions on patents in other fields. ${ }^{225}$

The second Article 30 limitation, that a patent exception not

221 See id.

222 Id.

223 See supra note 190 and accompanying text.

224 Compare TRIPS Agreement art. 30, with GATT art. XX.

225 This is not to argue that such restrictions might not be appropriate. 
unreasonably conflict with the owner's normal exploitation of it, ${ }^{226}$ poses fewer problems for countries seeking alternative pharmaceutical patent policies. Only a policy prohibiting a patent holder from exploiting its patent - such as the government/nonprofit non-commercial proposal discussed in the context of the public health provision ${ }^{227}-$ would potentially run afoul of this limitation. Even that proposal arguably would not "unreasonably" conflict with the patent owner's rights, but there is no need to make such a case in view of the TRIPS-legality of such a policy under the public health provision. All of the other options discussed in this paper would allow the patent holder to exploit the patent to whatever extent desired.

A nation challenging a Third World country's patent policy could argue that "exploiting" a patent includes the right not to use it or license it at all. This argument, however, would run contrary to the common use of "exploitation" which means to make use of, or to work up. ${ }^{228}$ This argument would require claiming that normal exploitation of a patent includes purposeful non-exploitation of it. That interpretation is more than the language can bear, since the drafters could have written "does not unreasonably conflict with patent holder rights" in the place of the exploitation clause had they intended to convey such a meaning. Moreover, the very next clause speaks to the "legitimate interests of the patent owner,"229 which would make the exploitation clause redundant were it to have the broad meaning required to include both exploitation and nonexploitation.

The third limitation - to not unreasonably prejudice the legitimate interests of the owner ${ }^{230}-$ is really the crux of the matter. This is especially true from the viewpoint of elaborating TRIPS-legal pharmaceutical patent policy. Critically, this limitation is itself limited, by a requirement to take into account the legitimate interests of third parties. ${ }^{231}$ In other words, it calls for a balancing process. A valid policy must balance the interests of patent-holding pharmaceutical companies in industrial-

${ }^{226}$ See TRIPS Agreement art. 30.

227 See supra section 4.2.1.

228 BLACK'S LAW DICTIONARY 579 (6th ed. 1990).

229 TRIPS Agreement art. 30.

230 See supra note 221 and accompanying text.

231 See supra note 216 and accompanying text. 
ized countries with the interests of Third World citizens and domestic pharmaceutical companies.

There is a strong case to be made that, in view of the pervasive government subsidies from which the industry benefits, the "legitimate interests" of the industrialized country pharmaceutical companies should be construed much more narrowly than the industry asserts. ${ }^{232}$ Third World countries seeking to invoke Article 30 do not need to rest their case on this argument alone. The equities of the balance lie heavily on the side of Third World consumers, who are overwhelmingly poor and unable to afford important drugs. Furthermore, unsanitary conditions and various conditions associated with poverty make Third World citizens more susceptible to illness than industrialized country consumers. ${ }^{233}$ The balance is further tipped in favor of permitting the less restrictive patent policies by virtue of the fact that Article 30 arguably allows "prejudice" to the interests of the patent owner, just not "unreasonable prejudice."234

Thus, Article 30 should permit some of the patent policy alternatives discussed in this paper, but it probably requires that they be carefully calibrated so as not to unreasonably or excessively infringe patent holder rights. ${ }^{235}$ In this regard, shortening the life of the patent for pharmaceuticals - as a means to promote the more rapid diffusion of lower-priced generics - seems to pass Article 30 muster, although exactly how much shorter patents could be made is unclear. At some point, shortening would arguably cross the threshold into "unreasonably prejudice" territory. Compulsory licensing would also be permissible under the balancing test - again to promote the diffusion of more affordable drugs to a poor population - but may require a royalty system to limit the degree of infringement of patent owners' interests.

Work-the-patent requirements would be harder to justify

232 See supra note 135 and accompanying text.

233 The interests of Third World domestic producers probably count for little in the balance, since developing local industry is an only minimally "legitimate" third party interest in Uruguay Round terms, if it is legitimate at all.

234 See Trips Agreement art. 30.

235 The adverb here is "unreasonably," not "unnecessarily," which suggests a much less strict standard than the least-trade-restrictive interpretation of Article XX. 
under Article 30, since they do not directly advance the public health interest in lower drug prices, but they too may be permissible. An argument on behalf of work-the-patent requirements would rest on two grounds. First, that promoting technology transfer is a legitimate interest of a third party, namely the country beneficiary of the transfer. Second, to the extent that work-the-patent requirements succeed at technology transfer and building up the domestic scientific base, they bring countries closer to developing their own independent research capacity. These research capacities could be directed to addressing local diseases for which the treatment, prevention, or cure does not hold out the prospect of sufficient profit to draw the interest of industrialized country pharmaceutical companies. That is, the argument would be that there is an indirect public health interest in work-the-patent requirements.

Article 30 would not permit a no-patent system. Even if such a system could be justified under the "unreasonable prejudice" clause, Article 30 only allows for exceptions "to the exclusive rights conferred by a patent," 236 meaning the patent itself must initially be granted. 237

\subsubsection{Article 31: Other Use Without Authorization of the Right Holder (Compulsory Licensing)}

Article 31 specifically authorizes countries to undertake compulsory licensing schemes, contingent upon meeting a series of provisions. ${ }^{238}$ These conditions include: ${ }^{239}$ (a) authorization for compulsory licensing must be considered on the individual

236 TRIPS Agreement art. 30.

${ }^{237}$ Note that this requirement does not affect the other alternatives discussed here. Compulsory licensing is clearly a limitation on patent exclusivity. For Article 30 purposes, so are work-the-patent and shorter terms provisions; work-the-patent provides for an exception to patent exclusivity where a patent holder does not use the patent as part of a manufacturing process in the granting country, and "shorter patent terms" - at least if properly drafted - provide for an exception to patent exclusivity at the end of a patent term.

${ }^{238} \mathrm{See}$ TRIPS Agreement art. 31. The existence of specific authorization for compulsory licensing in Article 31 does not preclude a compulsory licensing program under Article 30. Article 31 explicitly does not displace Article 30, but creates alternatives to member countries in addition to those made available under Article 30. See TRIPS Agreement art. 31, n.7.

${ }^{239}$ The lettering here tracks the lettering in Article 31. 
merits; (b) the licensee must have "made efforts to obtain authorization from the right holder on reasonable commercial terms and conditions and that such efforts have not been successful within a reasonable period of time;" (c) the scope and duration of the license can only be for specifically authorized purposes; (d) "such use shall be non-exclusive;" (e) the license must be nonassignable; ( $f$ ) the use of the license must be predominantly for the supply of the domestic market; (g) the license must "be terminated if and when the circumstances which led to it cease to exist and are unlikely to recur"; (h) "the right holder shall be paid adequate remuneration in the circumstances of each case, taking into account the economic value of the authorization;" and (i) and (j) the compelling of the license and the amount of remuneration must be open to judicial review. ${ }^{240}$

Most of these provisions pose little problem for the operation of an efficient compulsory licensing scheme. Provision (a) would require a government agency to oversee the compulsory licensing scheme, even where it maintained a strong presumption that it would require licensing for most drugs. This may add unnecessary bureaucracy, but it would not essentially impede a compulsory licensing program. It would provide the benefits of individualized review, enabling the government to permit exclusive production by the patent holder for "orphan drugs" - those which treat illnesses that do not occur in significant enough numbers to merit drug company involvement in the absence of a right to charge especially high prices.

Provision (b) should be cause only for minimal delay. The potential problem in provision (b) - determination of reasonable commercial terms - will be a consequence of the background understanding of adequate remuneration under provision (h). It does not by itself pose any additional difficulties for a compulsory licensing program. Provisions (c), (d), and (e) should pose no particular difficulties in the pharmaceutical context.

Similarly, provision (g) seems likely to have little restrictive effect on compulsory licensing schemes for pharmaceuticals. The circumstances giving rise to the compulsory scheme - poverty, high incidence of disease, etc. - are not likely to cease any time soon. And the judicial review required by provisions (i) and (j) should pose few problems, either. 
Provision ( $f$ ), however, while not fatal to a well-run compulsory licensing regime, creates substantial difficulties. Generic manufacturers can lower their marginal costs by expanding their demand pool, that is, by selling in other countries. And a rationally configured compulsory licensing scheme in many regions of the Third World might rely heavily on a common market approach, so that the countries of, for instance, East Africa would develop an integrated compulsory licensing and generic drug manufacturing and marketing approach. Provision (f)'s requirement that use be "predominantly" for domestic use seems to preclude the full elaboration of such an approach.

The critical potential obstacle to adoption of a compulsory licensing program under Article 31 is provision (h), requiring adequate remuneration be paid to involuntary patent licensors. What constitutes adequate remuneration? Provision (h) says only that "the economic value of the authorization" must be taken into account. But there is no single economic value of an involuntary license. As a general matter, the license will be worth more to the involuntary grantor - who is thereby forced to sacrifice monopoly profits - than it is to the nonexclusive grantee - who will only be able to earn competitive profits. The question then becomes: in the absence of any independent means to establish a level of adequacy, whose version of the economic value of the authorization should control the meaning of adequate remuneration? The TRIPS text does not provide an answer, but logic suggests the answer must be the value to the grantee. Where the value is set at the grantor's valuation, the patent holder would willingly grant the license without compulsion, and there would be no need for Article 31. In other words, defining adequate remuneration at the level of the involuntary grantor's valuation would swallow up Article 31 altogether. ${ }^{241}$

\subsubsection{Price Controls and Compulsory Licensing}

The TRIPS Agreement does not mention price controls, which remain legal under the Uruguay Round agreements as long as they

${ }^{241}$ I do not here consider what the value of the license is to the grantee, but it should be set at a level to allow the grantee reasonable profits. The royalty formula could be attached to the grantee's profit margin, or to gross sales. 
are administered in a non-discriminatory manner. ${ }^{242}$ In some cases, a government may find that price controls work well. But in many instances price controls are an unsatisfactory policy instrument, from the perspective of all players. Patent holders characterize price controls as severe and arbitrary, and sometimes more costly than compulsory licensing schemes. ${ }^{243}$ Furthermore, price controls are difficult for governments to administer, since they often require extensive investigation and negotiation with patent holders. Additionally, the inherent uncertainty of the enterprise is exacerbated because industry-provided data are somewhat suspect. Depending on implementation, price controls may be less beneficial to consumers, who, at least with some drugs, may find themselves paying higher prices than they would under an alternative scheme such as compulsory licensing. Furthermore, price controls do not benefit local, generic producers, who do not gain any enhanced right to or claim on multinational pharmaceutical company patents.

Given the industry-wide dislike of price controls, the system could be combined with a compulsory scheme to provide an independent TRIPS-legal basis for compulsory licensing. Pharmaceutical patent holders could be given a choice: accept price controls on the patented product or process, or agree to provide non-exclusive licenses to all domestic takers. ${ }^{244}$ In the context of an aggressively administered price control system, most companies would probably opt for the licensing alternative. This proposal would not have to meld itself to fit in the constraints of Article 31, because it would not constitute an allowance of use of the patent "without the authorization of the right holder."

Even within the framework of Article 31, the price-control-orlicensing option could address the most contestable issue in Article 31: determining the economic value of the authorization. In the context of a price control scheme, the economic value of a patent would be substantially lower than it would be were the patent

${ }^{242}$ Any discriminatory action is likely to be violative of general GATT principles of unequal treatment. See GATT art. XVII.

${ }^{243}$ See, e.g., Robert T. Abbott, Written Testimony Before the House Committee on Science, Space and Technology, FED. NEWS SERVICE, Sept. 28, 1994, available in LEXIS, News Library, Arcnws File (using his company, Viagene, as an example).

${ }^{244}$ See James Love, Patents Vs. People, Multinational MONITOR, June 1994 , at 22. 
holder permitted to charge unregulated, monopoly-profit-maximizing prices. Indeed, with an aggressively administered price control system, the economic value may be the same to both the licensor and the licensee.

\section{A Potential Alternative}

The central purpose of this Article is to argue that pharmaceutical patent policy alternatives remain viable under the TRIPS Agreement. The existence of these alternatives, however, is of little importance if none of the alternatives are attractive. This section first assesses the advantages of the alternatives for Third World countries, considers and largely rejects the arguments against the efficacy of the alternatives, and then proposes, in capsule form, an alternative pharmaceutical patent policy approach for Third World countries.

\section{5:1. The Benefits of Limiting the Patent Right}

The benefits of limiting the patent right accrue primarily to two Third World groups: pharmaceutical consumers and Third World generic manufacturers.

The benefit to the consumer is lower prices, meaning more affordable health care. By whatever means generic production is prompted - no patents or compulsory licensing, ${ }^{245}$ or shorter patent terms ${ }^{246}-$ prices will fall. The evidence on this point is irrefutable.

Schut and Van Bergeijk found that drug prices vary substantially across borders, ${ }^{247}$ and that direct price controls, bulk purchasing, promotion of the use of generics and abolishing patents all

${ }^{245}$ Obviously either option would bring generic competitors into the market almost immediately.

${ }^{246}$ In contrast, shorter patent terms would spark generic competition sooner than longer terms would.

247 See Frederick T. Schut \& Peter A.G. Van Bergeijk, International Price Discrimination: The Pharmaceutical Industry, 14 WORLD DEV. 1141, 1147 (1986). Specifically, a $10 \%$ increase in per capita income corresponds to an $8 \%$ increase in average drug prices. See id. Importantly, however, they note, "Although drug prices in developing countries are often lower than in developed countries, the real costs of these products, relative to the purchasing power of the population, are considerably higher (the real costs of drugs in Malawi are 12 times higher than in the United States ....). IId. 
work to lower pharmaceutical prices. ${ }^{248}$ The important implication of their finding that "drug prices vary arbitrarily, depending on the existence and degree of success of a national drug policy," they conclude, is that pharmaceutical companies will charge what the "market will bear."249 There is a lot of room for play in pharmaceutical prices, and sound and effective national drug policies can provide Third World consumers with substantial savings. ${ }^{250}$

The empirical evidence in support of the price-reducing effects of the introduction of generics is overwhelming. ${ }^{251}$ Empirical studies reveal that, "[o]ver time patents are a major factor in sustaining high drug prices; the appearance of generic competition results in prices of these drugs being much closer to the marginal production costs than those of brand name companies."252 In the United States, generic producers "enter the market quoting prices much lower than those of their branded competitors, and these prices also decline as the number of generic competitors increases, potentially falling to roughly seventeen percent of the branded producer's pre-entry price."253 In Canada, in 1983, when the country maintained a compulsory licensing system, "[t]he average price of compulsorily-licensed drugs sold by both the patent-holding and the compulsorily-licensed firms in Canada

248 See id.

249 See id.

250 See id. at 1148.

251 See id. (surveying the extent of the evidence).

252 Id. (providing anecdotal evidence of generics selling at one-tenth the price of their brand name counterparts in the United States).

253 Richard E. Caves et al., Patent Expiration, Entry and Competition in the U.S. Pharmaceutical Industry, in BROOKINGS PAPERS ON ECONOMIC ACTIVITY: MICROECONOMICS 1, 44-45 (Martin Neil Baily \& Clifford Winston eds., 1991). The authors further note that "[t]he effect of additional generic competitors is also noticeably stronger on generic prices than on branded ones." Id. at 45. Former patent holders are able to build on name recognition, consumer confidence and, importantly, relations with doctors to continue selling at a supracompetitive price to a substantial segment of the market. See id. at 46.

For a detailed study of the issue of substitution of generics in the United States for brand name drugs (by state-funded medical providers), the potential savings from substitution, and the cultural and institutional barriers to substitution, see generally AIISON MASSON \& ROBERT L. STEINER, FEDERAL TRADE COMM'N GENERIC SUBSTITUTION AND PRESCRIPTION DRUG PRICES: ECONOMIC EFFECTS OF STATE DRUG PRODUCT SELECTION LAWS (1985) (publishing a report from the U.S. Bureau of Economics of the Federal Trade Commission on the effectiveness of substitution law). 
was approximately half the prices prevailing in the United States for the same drugs;" non-compulsorily licensed drugs in Canada cost an average of eighty percent of the U.S. price. ${ }^{254}$ In India, the adoption of price controls and a process-only patents transformed Indian drug prices from among the highest in the world to among the lowest. ${ }^{255}$ And a no-patent system has driven down drug prices in Argentina as well. ${ }^{256}$ Indeed, industry representatives and consultants do not dispute the fact that generic producers drive down prices. Instead, their argument is that prices need to be maintained to enable drug manufacturers to recoup their investments. ${ }^{257}$

Limiting patent rights drives down prices because it facilitates entry of generic imitative products. ${ }^{258}$ Because the technological demands of producing an already patented product are substantially less than those of undertaking the research to create the patented product, less technologically sophisticated enterprises are

${ }^{254}$ H.C. Eastman, The Protection of Intellectual Property: Pharmaceutical Products in Canada, in MULTINATIONALS, GOVERNMENTS AND INTERNATIONAL TECHNOLOGY TRANSFER 153, 164-65 (A.E. Safarian \& Gilles Y. Bertin, eds., 1987).

255 See Weissman, supra note 85, at 10 (citing a report from B.K. Keayla, convener of the Indian National Working Group on Patent Laws).

256 See Love, supra note 245 , at 22 . In an advertising campaign in the United States in 1990, the Argentinean pharmaceutical manufacturers trade group highlighted the example of an anti-arthritis drug which sold in the United States for $\$ 169.84$, but only $\$ 35.08$ in Argentina. See Weissman, supra note 85 , at 10 .

257 See Clemente, supra note 109 , at 128-29.

Some observers argue that competition takes place among substitutable patented drugs. See Rapp and Rozek, supra note 98, at 90-96 (arguing that high costs associated with greater intellectual property protection for pharmaceuticals are often overstated because of incentives to find new uses for patented drugs and competition among these drugs); Parker, supra note 175, at 136 (suggesting that the high sales concentration in the pharmaceutical industry may often be accompanied by economic rivalry). To whatever extent this sort of competition does take place, however, it clearly does not have the pro-competitive effects of generics. If it did, patent holders would not care about generic competition, and prices would not fall so sharply with the introduction of generics. Moreover, to the extent that competition does take place among substitutable patented drugs, it is not entirely socially optimal. Much of the research money invested in substitute drugs could have been more profitably invested - from a social rather than private corporate viewpoint - in treatments for other ailments.

${ }^{258}$ See Clemente, supra note 109, at 129. 
able to produce generics. ${ }^{259}$ This provides an opportunity for fledgling companies in Third World nations with sufficiently large domestic markets. For example, India, Argentina, and Turkey have all developed flourishing domestic pharmaceutical industries in the last three decades. These are arguably the result of policies of granting no pharmaceutical patents (Argentina and Turkey) or imposing significant limits on them (India). ${ }^{260}$ Indeed, it was through imitation that virtually every industrialized country built up its technological capacity. ${ }^{261}$ Although industry-sponsored scholars claim that all technologically advanced countries maintain strong patent laws, virtually every industrialized country adopted strong patent laws after developing their technological infrastructure, ${ }^{262}$ in significant part through copying strategies. ${ }^{263}$ Many of the most industrialized countries have only permitted patents on pharmaceuticals in the last couple of decades. ${ }^{264}$

If promoting a domestic pharmaceutical industry is a goal of Third World policy makers, then limitations on patent rights are sensible. But those outside of Third World countries hoping to promote the development of domestic pharmaceutical industries should take a clear-eyed approach. Domestic industries are not a panacea for Third World ills. Based on his study of Turkey, Kirim concludes that domestic manufacturers engage in many of

259 See id.

260 See GEREFFI, PHARMACEUTICAL INDUSTRY, supra note 24, at 220-23 (discussing policies in Argentina); Arman S. Kirim, Reconsidering Patents and Economic Development: $A$ Case Study of the Turkish Pharmaceutical Industry, 13 WORID DEV. 219, 220 (1985) [hereinafter Kirim, Reconsidering Patents] (stating that in Turkey "[a]bolition of patents . . . was an important factor underlying the substantial growth of the locally-owned drug firms"); P.L. Narayana, Indian Pharmaceutical Industry: Problems E Prospects, MARGIN, Jan. 1984, at 39 (relating to India).

261 See Rapp \& Rozek, supra note 98, at 79.

262 See id.

263 Furthermore, in the information age - when new innovations build on the foundation of earlier inventions to an ever greater extent - there is reason to believe that copying is more important than ever if less industrialized nations do not want to consign themselves to permanent have-not status.

264 Germany and France first granted patents for pharmaceuticals in 1967, the Nordic countries in 1968, Japan in 1976, Switzerland in 1978, and Italy in 1979. See Laudeline Auriol \& Francois Pham, What Pattern in Patents?, OECD OBSERVER, Dec. 1992, at 15, available in LEXIS, News Library, Arcnws File. 
the same undesirable practices as their multinational counterparts. ${ }^{265}$ Most notably, Turkey experienced spurious product differentiation, as well as production and promotion of drugs irrelevant to major causes of mortality in Turkey. ${ }^{266}$ Nonetheless, domestic industries provide national benefits that multinationals do not. Domestic companies are more likely to adapt and modify technologies for local use than multinationals. ${ }^{267}$ They promote the development of the local technological infrastructure and favor generics. ${ }^{268}$ Furthermore, profits accumulated by domestic companies stay within the country, rather than flowing out and contributing to current account deficit problems. ${ }^{269}$ Finally, many Third World countries may desire to undertake a drug development policy geared toward meeting local needs that do not offer sufficient market incentives to attract the interest of multinationals. If a Third World country is going to rely on the private sector - rather than government entities - to market and perhaps do final stage development of the drugs, then it is likely to need a built-up domestic industry with which it can enter into

${ }^{265}$ See Arman S. Kirim, Transnational Corporations and Local Capital: Comparative Conduct and Performance in the Turkish Pharmaceutical Industry, 14 WORLD DEV. 503, 516-17 (1986) [hereinafter Kirim, Transnational Corporations].

266 See id. at 516.

${ }^{267}$ See Gary Gereffi, The Global Pharmaceutical Industry and its Impact in Latin America, in PROFITS, PROGRESS AND POVERTY: CASE STUDIES OF INTERNATIONAL INDUSTRIES IN LATIN AMERICA 259, $277-78$ (Richard S. Newfarmer ed., 1985) [hereinafter Gereffi, Global].

268 As Gereffi observes:

[M]any domestic private drug firms in the Third World contribute more to national goals of resource efficiency and equity than TNCs [transnational corporations] do. The motives underlying this socially desirable behavior are not altruistic, however. It just so happens that the self-interest of local firms and national development objectives often overlap. The tendency of local companies to reduce their reliance on foreign know-how because it compromises management control coincides with the Third World country's interest in technological autonomy. And whereas domestic enterprises favor bulk drug and generic product manufacture because the absence of heavy promotion and established brand names makes competition with TNCs easier, developing nations also prefer this strategy because it leads to increased vertical integration and lower drug prices, especially for essential items required by the poor.

Id. at 295.

${ }^{269}$ See id. at $277-78$. 
formal or informal partnership. ${ }^{270}$ Even in the late stages of product development, multinationals are not likely to pursue what appears from their perspective as only a niche market burdened by various government controls. ${ }^{271}$

\subsection{The Costs of Limiting the Patent Right}

Proponents of strict patent regimes contend strict regimes will benefit Third World nations. ${ }^{272}$ They assert that non-restrictive patent systems will inhibit foreign investment - and hence technology transfer - and dampen the development of an indigenous research and development capacity. ${ }^{273}$

As a preliminary matter, for some Third World countries, neither of these purported costs of limited patent rights may be a concern. ${ }^{274}$ For countries whose dominant or sole policy concern is with disseminating a core group of most important drugs at low prices - the "costs" of limiting the patent rights are not as significant. ${ }^{275}$

But even those countries which are concerned with attracting foreign investment and promoting local research and development should not be deterred from limiting patent rights. The claim that stronger patent protections fosters foreign investment is analytically suspect. In the context of pharmaceuticals, choosing the site for investments is based on factors wholly distinct from the patent protections afforded at the site. If Merck decides to set up research facilities in Switzerland, Switzerland's patent rules are

270 See Kirim, Reconsidering Patents, supra note 261, at 220. The existence of a domestic industry may be necessary but it is certainly not sufficient. Developing a local industry will not by itself automatically spark innovative research and development. See id.

${ }^{271}$ Cf. A. Samuel Oddi, The International Patent System and Third World Development: Reality or Myth?, 83 DUKE LAW J. 831, 834-44 (1987) (stating that foreign corporations are the most prevalent beneficiaries of patents in developing countries as "very few inventions are made by nationals").

${ }^{272}$ See Rapp \& Rozek, supra note 98, at 87-88 (noting that U.S. research and development expenditure abroad is predominately focused in Western Europe where intellectual property laws are adequate while falling in Latin American where the industry claims it is inadequate); see generally Mossinghoff, supra note 116 (describing the effect of the patent laws of foreign countries on American pharmaceutical research and development commitments).

${ }^{273}$ See Rapp \& Rozek, supra note 98, at 87-88.

274 See Parker, supra note 175, at 139.

${ }^{275}$ See id. 
probably irrelevant. It plans to recoup its investment in the international and primarily the U.S. market. The empirical evidence does not support the claim that limiting patent protections will result in decreased foreign investment. ${ }^{276}$ In Turkey, "abolishing patents ... has not adversely influenced the flow of direct foreign investment and the transfer of technology into the country."277 In Brazil, which eliminated patent protection for pharmaceuticals in 1969 in an effort to break the grip of multinationals over the local industry, foreign investment in the industry rose nearly six times in the 1970 s. $^{278}$

The more important claim by proponents of strict patent laws is that inadequate patent protection will impede local research and development, or multinational research and development designed to solve local problems. ${ }^{279}$ There is at least a grain of truth in this argument. It does seem likely that the promise of patent monopolies might induce some research which would not otherwise take place. ${ }^{280}$ However, this static analysis of the technological development process ignores the fact that Third World countries may not have the domestic capability to undertake that sort of research. That capability may depend in part on building up a domestic industry through pursuit of a nonrestrictive patent policy. Moreover, to the extent that strict patent protection is necessary to induce research, that protection still must come at the expense of the consumer and national interest in lower drug prices. There is no reason to believe that the twenty year exclusive terms mandated by the TRIPS Agreement $^{281}$ strikes the proper balance. To the extent there is a need for a balance, it calls for careful calibration by policy makers administering price controls, or setting the royalties in a compulsory licensing system, or determining the length of domestic

${ }^{276}$ See Schut \& Van Bergijk, supra note 248, at 1142.

27 Kirim, Reconsidering Patents, supra note 261, at 220.

${ }^{278}$ See Gereffi, Global, supra note 268, at 289.

279 The literature supporting this contention is extensive. See, e.g., Parker, supra note 175, at 139; Rapp \& Rozek, supra note 98, at 79.

${ }^{280}$ Note that this assumes the Third World companies are domestically oriented, and primarily not looking to export to industrialized countries with strict patent protections. If this assumption is incorrect, then local companies should receive sufficient inducement from patent protections in the industrialized countries.

281 See TRIPS Agreement art. 33. 
patent protection. "Ideally," concludes F.M. Scherer, perhaps the leading scholar of compulsory licensing, "we would like a flexible policy - one that can be 'fine-tuned' to individual circumstances. Despite this caveat, I am persuaded that technical progress would not grind to a halt if a uniform policy of compulsory licensing at 'reasonable royalties' ... . were implemented." 282

Historical and recent empirical experience suggests Scherer's claim is correct. It seems that proponents of strict patent policies have vastly exaggerated whatever merit their argument may have. After all, many industrialized countries developed pharmaceutical industries in the absence of patent protection. Moreover, those Third World countries not adopting strict patent policies have proven more innovative than those who have. ${ }^{283} \mathrm{~J}$. Davidson Frame, after conducting a global survey and regression analysis, finds that countries with a low commitment to supporting intellectual property laws ("LOWCOMM countries") have, on average, notably larger scientific and technological capacities than other Third World countries. ${ }^{284} \mathrm{He}$ also finds that LOWCOMM countries patent more heavily in the United States than do other Third World countries. ${ }^{285}$ Frame concludes that "it becomes increasingly difficult to accept arguments by LOWCOMM countries that they are weak, helpless actors in the international system who need special protection"286 and that the LOWCOMM countries maintain a "double standard."287 But he strangely misses the more notable implication of his findings: those countries with less restrictive patent protections have developed stronger domestic research capacities while at the same time becoming more innovative.

There are unquestionably legitimate concerns about the degree of innovation in Third World countries. But the claim that low

282 F.M. SCHERER, THE ECONOMIC EFFECTS OF COMPULSORY PATENT LICENSING 85 (Edwin J. Elton \& Martin J. Gruber eds., 1977).

283 See J. Davidson Frame, National Commitment to Intellectual Property

Protection: An Empirical Investigation, 2 J.L. \& TECH. 209, 215 (1987).

${ }^{284}$ See id.

285 See id. at 216.

286 Id. at 215.

${ }^{287}$ See id. at 216-17 ("These countries have been identified by various sources as having the most flagrant disregard for intellectual property among the countries of the world, yet they are first among Third World countries to take advantage of intellectual property protection offered in the world's largest market.") 
levels of research and development are caused by inadequate patent protection is dubious. What is missing to a greater or lesser degree in most Third World countries is a science and technology infrastructure - a national system of advanced education and research. A patent system simply cannot provide those things.

\section{CONClusion: Formulating AN ALtERnATIVE}

The primary concerns of a rational drug policy for Third World nations should be disseminating useful drugs as widely and cheaply as possible, and encouraging research and development of products to address local illnesses. ${ }^{288}$ These will often include tropical diseases that do not draw the attention of corporations from industrialized countries. ${ }^{289}$

As I have alluded earlier, I believe a critically important approach to the first of those goals is the adoption and implementation of an Essential Drugs program. ${ }^{290}$ But Essential Drugs programs relate only tangentially to patent policy, and are outside of the scope of this paper.

Within the realm of patent policy, the best means to achieve the first goal - of providing drugs widely and cheaply - is to promote generic production. I believe compulsory licensing - in conjunction with price controls if necessary to pass TRIPS muster - is the most feasible means to promote generics. Compulsory licensing is a decentralized, anti-bureaucratic means to ensure the rapid development of generics once the system is legislated into place or otherwise adopted. It is structurally pro-competitive, and hence not easily susceptible to corruption, incompetence, or lack of resources.

The development of the domestic industry as an outgrowth of a compulsory licensing system may aid in the creation of an indigenous research capacity and in promoting research on local illnesses. Historical experience shows, however, that developing

288 See Gereffi, supra note 187, at 276-77 (exploring the often inappropriate mix of pharmaceuticals offered in Third World nations).

289 See, e.g., id. at 276 (pointing to India where the most prevalent diseases include malaria, dysentery, and filariasis, but pharmaceutical sales focus on vitamins, cold medicines, and "health restorers").

290 On the case for essential drugs programs, see generally MELROSE, supra note 175 . 
a domestic industry will not accomplish these goals by itself. To achieve these ends, Third World nations should look to the example of the United States - not for its patent law, but for its biomedical infrastructure, which is crucially dependent on government funding. ${ }^{291}$ Collective action problems and other factors affecting corporate incentive, structure, and organization preclude private industry by itself from accomplishing what government funding can: development of an indigenous capacity in basic and early-phase applied research which creates breakthrough advances and spins off into commercial applications. With very few exceptions, however, Third World nations do not have available funds easily diverted into biomedical research programs in national universities or laboratories. There are, however, at least two attractive options to generate these monies. First, a percentage of royalty payments to patent licensors could go to a national biomedical fund. ${ }^{292}$ Second, a national tax could be placed on all drug sales, or, preferably, on all nonessential drug sales, with the resulting revenue also directed to the national biomedical fund.

This collection of proposals would be: non-discriminatory in GATT terms; compatible with the TRIPS Agreement; an effective method of attending to the pharmaceutical-related public health needs of the poor segments of the population; and an effective means to overcome the spurious tradeoff between fair prices and research posited by proponents of strict patent policies.

The key to implementing reforms of this sort is conceptualizing and promoting them as legitimate and valid policy choices. Once they have crossed the threshold of legitimacy in practical, political, economic, legal, and metaphoric terms, they can be considered on their merits. This will provide the best ultimate chance of popular acceptance and approval, and, ultimately, implementation.

291 This portion of this Article's proposal elaborates on suggestions made by James Love. See Love, supra note 245, at 24.

${ }^{292}$ This can be conceived of as an amount separate from the royalty, a tax on the royalty or a portion of the royalty - all three are essentially the same. 